Number 69 - January 2008

\title{
How effective are poor schools? \\ Poverty and educational outcomes in South Africa
}

Servaas Van der Berg

Georg-August-Universität Göttingen 


\title{
How effective are poor schools? Poverty and educational outcomes in South Africa ${ }^{*}$ \\ Servaas van der Berg \\ Department of Economics \\ University of Stellenbosch \\ Stellenbosch \\ South Africa \\ Email: $\underline{\text { SvdB@sun.ac.za }}$
}

\begin{abstract}
Massive differentials on achievement tests and examinations reflect South Africa's divided past. Improving the distribution of educational outcomes is imperative to overcome labour market inequalities. Historically white and Indian schools still outperform black and coloured schools in examinations, and intraclass correlation coefficients (rho) reflect far greater between-school variance compared to overall variance than for other countries.

SACMEQ's rich data sets provide new possibilities for investigating relationships between educational outcomes, socio-economic status (SES), pupil and teacher characteristics, school resources and school processes. As a different data generating process applied in affluent historically white schools (test scores showed bimodal distributions), part of the analysis excluded such schools, sharply reducing rho. Test scores were regressed on various SES measures and school inputs for the full and reduced sample, using survey regression and hierarchical (multilevel) (HLM) models to deal with sample design and nested data. This shows that the school system was not yet systematically able to overcome inherited socio-economic disadvantage, and poor schools least so. Schools diverged in their ability to convert inputs into outcomes, with large standard deviations for random effects in the HLM models. The models explained three quarters of the large between-school variance but little of the smaller within-school variance. Outside of the richest schools, SES had only a mild impact on test scores, which were quite low in SACMEQ context.
\end{abstract}

JEL Classification: J210

Keywords: Analysis of Education

\footnotetext{
1 Revised version of paper delivered at SACMEQ International Invitational Research Conference, Paris, September 2005. The author wishes to thank Derek Yu for technical assistance with the data and Megan Louw, Ronelle Burger, Kenneth Ross and Neville Postlethwaite for useful comments.

* The paper has been presented at the cege research colloquium, University of Göttingen, November 2007.
} 


\section{Introduction}

Massive differentials on achievement tests and examinations reflect South Africa's divided past. Despite narrowing attainment differentials, unprecedented resource transfers to black schools and large inflows of black pupils to historically white schools, studies have shown that historically white and Indian schools still far outperform black and coloured schools in matriculation examinations and performance tests at various levels of the school system. Moreover South African educational quality lags far behind even much poorer countries, as has been demonstrated by a number of international tests, including MLA, TIMSS and now SACMEQ II. Educational quality in historically black schools - which constitute 80 per cent of enrolment and are thus central to educational progress - has not improved significantly since political transition. Inadequate educational progress constrains both black upward mobility in the labour market and the skills required for economic growth in a middle-income country.

Thus a better understanding is required of the factors that inhibit performance in poorer, mainly black or coloured schools. This paper attempts to improve understanding of the role of socio-economic status (SES) and other factors in determining educational performance at the Grade 6 level. Such performance affects drop-outs, transitions between grades and quality of educational performance up to matriculation and beyond.

Studies have shown high variability in school performance (large residuals) after controlling for SES and teacher inputs that may be indicative of varying efficiency, hinting at managerial problems in many schools (Crouch and Mabogoane 1998). Because of data limitations, education production function studies thus far have had to use school examination performance for matriculation (Grade 12) and have largely ignored non-teacher school inputs and processes. SACMEQ II's rich individual and school level data provide new possibilities for investigating interactions between educational outcomes, SES, school resources and teacher inputs, thus moving towards an understanding of how and under which conditions resources improve outcomes. As it appears that quite different processes may determine learning outcomes in affluent schools (bimodal distributions of test scores provide evidence of separate data generating processes) and the focus here lies predominantly on the performance of the resource-scarce formerly black school system, part of the analysis excludes affluent schools. Test scores will be regressed on SES, pupil characteristics, school inputs, school processes and location for the full and reduced sample, using Stata's survey regression and hierarchical (multilevel) (HLM) models to deal with sample design and nested data. This should help to advance understanding of the conditions required for resources to have an 
optimal impact, as earlier work indicated that resources mattered only conditionally on school efficiency (the ability to convert resources into educational performance, whilst controlling for SES),), which varied widely amongst schools.

The paper proceeds in the following way: First, South African educational inequality between schools is discussed and placed in international perspective, to show that such inequality is indeed a large part of the education challenge in this country. The paper then turns to a brief discussion of the SACMEQ II South African data. Thereafter, an analysis of performance is attempted by focusing on both school and pupil performance, using OLS (ordinary least-square) regressions but allowing for clustering effects in sample design. The next step is an analysis of performance of poorer schools (a reduced sample), to try to exclude most formerly white schools that could perhaps best be seen as functioning on the basis of a different data generating process. This procedure assists in capturing the relationships amongst individuals in schools that were not formerly advantaged, so that the coefficients can better be interpreted as applying amongst such schools. If the same analysis was applied to all schools, then the coefficients would instead reflect differences between historically white and historically black schools. Next, quantile regression is used for the same purpose, viz. to model the differences between performance of children in well and weakly performing schools. School rather than individual performance is briefly modelled next, as a prelude to the final modelling. The final form of analysis employed here is the estimation of a two-level HLM which attempts to incorporate the effects of both individual and school characteristics, focusing particularly on the role of SES. The paper closes with an overall conclusion.

\section{Inequality between schools}

The intraclass correlation coefficient rho $(\rho)$ - which expresses the variance in performance between schools as a proportion of overall variance - is extremely high in South Africa. The Kenya SACMEQ II report (SACMEQ 2005: Ch.8, p.14) quotes Willms and Somers' (2001) finding that the intraclass correlation coefficient ranged from 19.5 per cent to 41.2 per cent for mathematics achievement for Grade 3 and 5 pupils in 13 Latin American countries. Rumberger and Palardy (2003: 14) report a value of 25 per cent to be "within the range that Coleman found in his 1996 study and the range found in other recent studies of student achievement using similar models". In calculating required sample sizes, SACMEQ II erroneously assumed that rho for the group of countries investigated would be in the range of 0.3 to 0.4 , thus underestimating the number of schools that needed to be sampled for the desired significance (Ross, Saito, Dolata, Ikeda, Zuze, Murimba, Postlethwaite and Griffin 
2005: 26). Table 1 below shows the range of this magnitude from three sets of international studies, arranged by the rho values for the reading scores in cases where both reading and mathematics were tested. The SACMEQ 2000 rho values of 0.70 for South Africa's reading scores and 0.64 for the mathematics scores confirm that inequality in performance between schools in South Africa is exceedingly high. South Africa has by far the highest recorded values, with Namibia its closest rival by this measure of the degree to which inequality applies between rather than within schools. Although the intraclass correlation for the 2003 matriculation results is considerably lower at $0.399^{2}$, it is unlikely that this means that the SACMEQ data overestimated the South African rho: An unpublished Western Cape study at primary school level also found a value of 0.72 for reading, but a much lower value for mathematics (0.44), perhaps reflecting more individual variation in mathematics performance.

This high degree of inequality between schools is largely a legacy of historical educational inequality. However, it arises more from differences in educational quality than from differential attainment, since the latter has narrowed considerably in recent decades. Indeed, Lam (1999) found that South African attainment differentials between race groups had narrowed faster than in Brazil - a country with income inequality levels similar to South Africa's.

The differentials in performance between high and low SES groups, or rich and poor, far exceeded that in other SACMEQ countries in both reading and mathematics, judging by the SACMEQ indicators and their SES measure (SACMEC Indicators 2005). The differences in mean scores of rich and poor shown in Figure 1 illustrate how far South Africa leads the field in this measure of educational inequality. Namibia (for reading) and Mauritius (for mathematics) were closest to South African differentials between rich and poor. Figure 2 shows a similar picture, for the differential in scores between large cites and isolated rural areas. Here, South African differentials were massive: there was urban-rural gap (as here defined) of almost 180 score points for reading and almost 140 for mathematics. This is put

\footnotetext{
2 This may reflect one or both of these factors:

- Differences in transition and drop out rates, that prevent weaker pupils from reaching matric, thus reducing variance both within and particularly between schools.

- Weaker quality differentiation in the matric examination, due to the wide subject choice allowed. However, the intraclass correlation coefficient of the Mathematics mark of those who did take this subject was only 0.389 in 2003 (the Standard Grade mark converted to Higher Grade by subtracting 10 percentage points). But this value was also reduced by self-selection: Those who were weaker at mathematics avoided the subject.
} 
into perspective when one considers that mean test scores have been set at 500 and the standard deviation at 100 across all SACMEQ countries, and that only Namibia had differentials more than half as large. The differentials also did not arise so much from exceptional performance of the rich or the urban populations than from relatively poor performance amongst the poor and those in isolated rural areas. This weak educational performance of large segments of the population is put into further perspective when it is considered that South Africa had a much higher per capita income than most SACMEQ countries.

Lowess (locally weighted) regressions of the relationship between the SES derived for this study (discussed below) and test scores had very similar shapes for individuals and school averages for both reading and mathematics (Figures 3a, 3b, $4 \mathrm{a}$ and $4 \mathrm{~b}$ ). This relationship was quite flat over most of its range, particularly for individuals. Apparently, SES only started playing a role at a higher, threshold level of SES. At low levels of SES, individuals and indeed schools did not seem to gain much in terms of reading or mathematics score improvement from higher SES. This may indicate that most schools were not able to turn higher SES, at least up to that threshold, into educational advantage. This cannot be taken as evidence that such schools performed well in enabling poor children to perform almost as well as those from middle class backgrounds, as these scores were low in SACMEQ perspective. It was rather the case that the ineffectiveness of these schools meant that not even middle class children performed well. Many of the individuals above the SES threshold level were white and Indian pupils (slightly more than 10 per cent of national school enrolment, though because of varying school size it is uncertain what proportion of schools they constituted) who were historically clustered in schools that performed much better than average. These schools had been racially desegregated, but still largely served the highest SES groups. Based mainly on evidence for secondary schools (i.e. matriculation results), it has been argued that such schools still far outperform others (Van der Berg \& Burger, 2003). The data shown here indicate that this argument also applied at primary school level.

The differentials in performance are also shown by school quintiles, where schools are arranged according to their mean SES. Table 2 shows that mean performance per quintile remained very flat between the poorest and third poorest quintiles (for reading, it rose by only 6 per cent, with no difference in mathematics performance). From Quintiles 3 to 4, performance rose a little more, by another 10 per cent for reading and 8 per cent for mathematics. However, the richest quintile performed more than 25 per cent better than the second richest quintile in both reading and mathematics. Clearly, the richest quintile of 
schools far outperformed the rest. This makes s strong case for excluding them from the sample for the analysis that focuses on non-affluent schools.

The table also shows that only a few more than one third of South African pupils performed above the SACMEQ mean of 500 on each of the two tests. This proportion increased strongly across the quintiles, with the largest jump occurring when moving from the second richest to the richest quintile. The proportion of each quintile with marks below 400 (one standard deviation below the SACMEQ mean) remained very similar across the bottom three quintiles for both reading and mathematics, but dropped to a negligible share in the richest quintile.

\section{The data}

The SACMEQ II survey was conducted mainly in 2000 in 14 countries of Southern and Eastern Africa by the Southern African Consortium on Monitoring Education Quality, based on complex two-stage clustered samples. Questionnaires were administered to selected pupils, their reading and mathematics teachers, and their school principal. A chapter in the Kenya SACMEQ report by Ross et al. (2005) provides more detail on sampling and all stages of the process from the planning stage. In South Africa 169 schools were sampled, but because of some missing values on some of the variables (mainly interviews with principals), the actual sample in much of the analysis was reduced to 167 schools. Altogether 20 children in each school were to be tested, but again there were a few missing observations for some variables in the final data set. After allowing for these, the full sample of pupils stood at 3163 . Applying pupil weights, this sample was broadly representative of the South African Grade 6 population, and - as almost universal school attendance had been achieved up to about age 16 - was also likely to be representative also of the 12 year old age group (note that repeaters and those who started school early affected this slightly). However, SACMEQ acknowledged that the effective sample (after taking cognisance of cluster effects in sample design) was smaller for South Africa than is the norm: "In the SACMEQ II Project, two school systems, South Africa and Uganda, fell far below the required target of an effective sample size of 400 pupils. In South Africa the values were 185 and 230 for reading and mathematics, respectively ..." (Ross et al., 2005). This largely resulted from the intraclass correlation being larger than allowed for in the sample design, thus too few South African schools were selected. In South Africa. "Ministry concerns about the validity of sampling and measurement" were noted with the release of the SACMEQ II data, leading to a delayed release of the data for this country (see SACMEQ, 2004). 
A large number of variables were generated by SACMEQ II, as described in more detail in Ross et al. (2005) and elsewhere in the SACMEQ II Kenya Report (2005). These variables were largely the ones used for this study, bearing in mind that in South Africa teacher reading and mathematics skills were not tested (these skills were tested in all the other SACMEQ countries). Furthermore, an own SES variable was created, as described below.

The main variables used in the analysis can be grouped as follows:

- Pupil-level variables: Pupil age, gender, number of times a grade was repeated, whether a pupil always or sometimes spoke English at home ${ }^{3}$, education status of pupil's parents, whether the pupil lived with his/her parents, variables relating to the existence of various household possessions, the materials the pupil's home were constructed from, the schoolrelated items (e.g. pencils, rulers, etc) the pupil possesses, and the availability of textbooks. In addition, information was also obtained on the pupil's absence from school and the reasons for such absence.

- Teacher-level variables: For both reading and mathematics, the teacher of each pupil was interviewed to obtain information on gender, age, training, and some SES variables. As not all pupils in each school sample came from the same class, in some schools more than one teacher was interviewed in each subject.

- School variable: Information on the gender, age and training of school principals was obtained, as well as information on reported school problems relating to pupils or teachers.

- School resources: Classroom and other facilities, school building, and school equipment were all recorded.

- School location: Three types of areas were distinguished, viz. large cities, towns, and isolated rural areas.

- School processes: This included frequency of homework, frequency of correction of homework, visits by inspectors, and test frequency.

Socio-economic status of pupils is an important determinant of learning outcomes. The question in this case was how best to measure SES. The approach used by SACMEQ itself, while useful, included parent education - which was regarded as an important regressor to include separately in this study. A new SES variable was thus rather created, using the first factor in principal component analysis that included as variables possessions in and services used by the household (e.g. having a newspaper in the home, ownership of a radio, a

\footnotetext{
${ }^{3}$ The test was conducted in English, one of South Africa's eleven official languages, although only 14 per cent of pupils reported always speaking English at home.
} 
television set, a fridge, a car, having electricity, a telephone), the type of house (judged by the wall materials) and the quantity of a list of stationery items that the pupil had in school. The SES variable constructed in this manner showed a high correlation with many of the variables one would expect it to be associated with, whilst its average value was much higher for pupils attending schools in large cities than those in towns or isolated rural areas.

The variables used are summarized in Table 3, along with their mean values, standard deviations, minima and maxima.

\section{Regression analysis: Full sample of individuals and schools}

For the regression analysis, the broad underlying model was that SES, pupil characteristics (age, gender, repeater status), access to textbooks, academic effort (as proxied by homework frequency), teacher characteristics (age, gender, training, and tertiary qualifications), school resources, school location, school processes, teacher and pupil problems experienced in the school (violence, pupil behaviour, health, etc.) and perhaps also the characteristics of the school principal may have played a role in determining learning outcomes, in addition to the unobserved ability of the individual pupil. As ability was unobserved, care should be taken in the interpretation of the models of possible ability bias that may influence results. The modelling approach taken was general to specific, initially including all variables deemed potentially relevant to the equation, but selectively dropping those found not to be significant. A few control variables usually considered to be standard explanatory variables in the education literature - including SES, pupil gender, mother's education, over age pupils, and provincial dummies (with NorthWest the reference province) - were retained irrespective of their statistical significance or sign. As the sample of individual children was clustered in schools, thus reducing heterogeneity, all regressions adjusted for sample design and weighting of individuals using Stata's survey regression cluster option. Huber-White robust standard errors were generated to deal with possible heteroskedasticity, thus ensuring stringent tests of variable significance.

The models fitted are as interesting for the variables that were retained as for those that failed to enter the regressions significantly or with an appropriate sign - see Table 4, regressions 1 and 2 for the full models for reading and mathematics respectively. Pupil SES was an important predictor, but the effect appeared to be non-linear. A quadratic function gave a better fit than a simple linear model for in both reading and mathematics, with SES affecting scores little at low levels of SES, but playing an increasing role at higher SES levels, as the lowess regressions had indicated may be the case. Other pupil characteristics that 
played a role in explaining academic performance included gender, age, home language and household structure. It is noticeable that males did worse on reading than females, but there was no significant gender difference for mathematics. The gender dummy was nevertheless retained as a control variable in all regressions. Overage children (above 12 years) performed just over 20 marks worse on both the reading and mathematics scores, whilst underage children had a disadvantage in mathematics. As the test was conducted in English, it was no surprise that speaking English at home brought strong benefits in terms of performance. It is interesting, however, that there was little difference between always speaking English at home and sometimes doing so. In this country of highly fragmented family structures, pupils who lived with their parents had a strong advantage in both reading and mathematics.

Turning to variables directly related to schooling, pupil attendance, grade repetition, parents' education and household resources appeared to be important determinants of academic success. Pupil absence from school had the expected negative impact on marks, and the effect was particularly large in the case of reading marks if such absence was due to unpaid school fees ${ }^{4}$. As the model already controlled for SES and fees were quite low in most schools, unpaid school fees probably partly proxied for a weaker commitment to education by less affluent and probably less well educated parents. It did not appear as if repeating grades brought pupils to the performance levels of their peers, as repeaters fared progressively worse the more years of schooling they had repeated. Although the coefficients on the repetition dummies were not all individually significant and did not show such a regular pattern for mathematics, a joint significance test showed that they did have the expected combined effect. Whilst having a mother with matric brought measurable benefits in terms of a child's reading performance, a child required his or her mother to have obtained at least a degree before the benefits of maternal education were reflected in mathematics scores. By contrast, father's education did not show significant effects. The positive impact of having more than 10 books at home was probably mainly another manifestation of home background, literacy and attitudes to knowledge.

Not having an own textbook or having to share it with more than one other pupil was associated with worse scores on reading. Interestingly, homework frequency did not lead to any significant improvement in performance when the full sample was considered.

Equipment, measured on a scale of 0-11 (a count of the presence of a first aid kit, fax machine, typewriter, duplicator, radio, tape recorder, overhead projector, TV, VCR,

\footnotetext{
${ }^{4}$ Note that this result obtained even though schools were formally forbidden from applying sanctions against pupils whose fees were unpaid.
} 
photocopier, and computer present in the school), played a positive role. In the case of mathematics, school buildings (measured on a scale of 0-6: a count of the presence of a school library, school hall, teacher room, office for school head, store room and cafeteria) also impacted scores positively. Teacher training or tertiary qualifications did not enter the models as significant factors. Urban schools in large cities performed much better than others, but there was no indication that schools in towns performed better than those in isolated rural areas. Where principals reported having teacher problems, reading scores were significantly lower, although not by a large magnitude. The same result did not apply to mathematics scores.

The pupil-teacher ratio (representing class size) did not significantly enter either of the models, or entered them with the wrong sign, showing that the availability of this type of resource was not as important as often thought. This confirmed earlier work that suggested that teacher numbers play a limited role in South Africa (Crouch \& Mabogoane 1998; Van der Berg \& Burger 2003), particularly since apartheid era disparities in the allocation of publicly remunerated teachers between schools were eliminated. However, as in many other countries, the quality of teachers may have been more important than the quantity in which they were employed. Another relevant issue here was that, despite government's attempts at standardisation of the pupil-teacher ratio, two factors still contributed to maintaining de facto disparities in this measure of school quality. Firstly, schools could impose school fees to supplement public resources, and richer schools often used such funds to appoint teachers in addition to those on the public payroll. Secondly, some schools may have had difficulty filling positions - particularly schools located in deep rural areas. A factor that may have been even more decisive for education quality in poor schools was that good teachers were likely to prefer teaching in richer, urban schools. In view of the remaining differences in allocations of publicly remunerated teachers and those appointed by the school governing body, the very low correlation between mean SES of schools and pupil-teacher ratio or class size (for both, $r$ $=-0.17$ ) was surprising. It is not clear whether this was the result of poor reporting on pupilteacher ratios, or whether factors other than teacher and pupil numbers (e.g. administrative and other duties that kept some teachers out of classes) conflated the relationship between class size and SES.

\section{Regression analysis: Reduced samples}

The intraclass correlation coefficient referred to earlier was substantially decreased if the sample was reduced by first dropping the richest 10 per cent of schools (numbering 17) 
from the sample, and then the next 10 per cent as well, as Table 1 shows. The affluence of a school was measured by the mean SES of its pupils in the sample. The full sample reduction reduced rho from 0.70 and 0.64 for reading and mathematics, to 0.47 and 0.39 respectively. This large reduction reflected the fact that a major part of the educational performance disparity in South Africa was between rich (mainly historically white and Indian) schools and other schools. It may indicate that the superior performance of richer schools was due to both having pupils with greater private resources (evidenced by a higher SES and having more educated parents) that enhanced their schooling outcomes, and greater school efficiency in converting school and pupil inputs into performance outcomes for pupils of any given SES. Such conclusions about school efficiency in South Africa have been discussed before in Crouch \& Mabogoane (1998 \& 2001) and Van der Berg \& Burger (2002). If such schools do operate differently, then there is a strong case for excluding white and Indian schools from the sample for the regression analysis. Two separate data generating processes may indeed have been at work, where the underlying statistical relationships would have been conflated by treating them as one. If this conception of the world was correct, then the historically white and Indian schools were best regarded as outliers which may have unduly influenced the estimated coefficients in regressions estimated for the entire schooling system.

Table 5 shows the effect of reducing the sample in terms of scores at the school level. Mean school SES scores drop quite considerably, but even more dramatic was the decline by almost half in the standard deviation across schools. Note also that the maximum values dropped precipitously.

There was no information on the former race-based department to which schools in the sample belonged. However, it was known that race and SES were still highly correlated and that historically white and Indian schools constituted a little more than 10 per cent of all schools in South Africa. To remove these schools from the data set, the sample was reduced twice in the manner described above: first the richest 10 per cent of schools were dropped, and then the next 10 per cent The same parsimonious regression was then run on the original sample as well as on the two reduced samples to see whether sample reduction strongly affected the results.

If all the data captured the same underlying relationship, then the coefficients in the three regressions should have been very similar. If on the other hand all former white and Indian schools functioned quite dissimilarly according to a different data generating process, and most were to be found in the top 10 or to 20 per cent of schools by SES, then the estimated coefficients in either or both of the reduced samples should have differed 
substantially from those in the original regression. This was indeed the case, as can be seen in Table 6 for both the reading and mathematics scores: Regression equations altered fundamentally when the sample was reduced. This was best illustrated by the magnitude of the coefficient for SES, which declined for the reading scores from 9.022 in the full sample to 6.883 in the 10 per cent reduced sample and to 3.991 in the 20 per cent reduced sample. This showed that the large and significant coefficient for SES in the original sample may perhaps just have meant that richer (mainly historically white and Indian) schools performed much better, since once they were removed from the sample, the effect of SES on test scores was much smaller. For the mathematics score, the coefficient fell from 6.295 to 2.996, and finally to 0.602 . At this point, the coefficient was no longer statistically significant, indicating that SES appeared to play no role in mathematics performance in historically mainly black and coloured schools. The sharp change in the coefficients with both changes in the sample may indicate that white and Indian schools were distributed across the top 20 per cent rather than only the top 10 per cent of schools by SES in the sample. Other coefficients changed with the sample reductions too, and in the case of mathematics scores even the urban dummy lost its significance as a predictor of performance when more affluent schools were dropped.

The next step was to focus on the reduced sub-sample of mainly black and coloured schools, so as to estimate the most appropriate regression models for this group of schools. Separate models were fitted again in the same manner as before for reading and mathematics scores. The results are shown in regressions 3 and 4 of Table 4.

The models showed much lower coefficients on most of the regressors than in the full sample, as was already discussed for the basic parsimonious model in Table 6. Again, females had an advantage in reading that disappeared in mathematics, whilst the coefficients for speaking English became stronger. The reduced sample related to a group amongst whom speaking English - the language of the tests - was uncommon, and thus using the language at home was expected to give pupils an advantage in tests. Socio-economic status was significant in linear rather than non-linear form for reading, but not for mathematics. The same finding applied to urban residence, which was consequently dropped from the mathematics model. A mother with a degree represented an advantage for children's performance in both reading and mathematics, although maternal education at lower levels surprisingly did not provide any measurable benefits. Living with parents remained highly significant, but the variable relating to the presence of books at home was (surprisingly) no longer significant and consequently was dropped from both models. Absence from school remained significantly negative for both mathematics and reading, while school absence 
related to not paying school fees also had a significantly negative impact on reading scores. Repeating school grades remained highly negative.

Reading scores were affected by homework, although mathematics scores were not. In the model for the full sample, homework was not a significant positive determinant of performance for either reading or mathematics. Thus homework appeared to matter for explaining reading performance amongst the non-affluent schools, whilst having no textbooks negatively affected reading scores but not mathematics scores.

Overall, the model's explanatory power was much weaker than that of the model for the full sample. This is a similar result to that found by Van der Berg and Burger (2003). The lower coefficient of determination compared to its equivalent for the full sample resulted largely from the fact that all the regressors available for non-affluent schools did not appear to be able to provide as good a model of systematic relationships with performance. The greater unexplained variability in performance was probably - as has been argued before by Crouch and Mabogoane (1998) - an indication of the varying school efficiency that existed in a large part of the school system.

However, reducing the sample to only non-affluent schools did affect reading scores. This is explored further in the next section.

\section{Regression analysis: Quantile regression}

An alternative way of dealing with the different data generating processes that may be present in the sample was to use quantile regression, where the coefficient reflected the different levels or types of functioning of the underlying model for individuals performing at different levels in the overall distribution, given their characteristics and school situation. Table 7 shows quantile regressions of the basic models for both reading and mathematics at the median $\left(50^{\text {th }}\right.$ percentile $)$ and at the $80^{\text {th }}$ percentile, which may give some indication of the varying relationships in schools from different former racially based school systems. The slope and dummy coefficients were usually flatter for the median regression, reflecting both the smaller range of scores and the earlier observation that the relationship between scores and explanatory variables was much stronger in better performing schools - which were also often richer ones. This can be seen as that the returns to characteristics were much higher in richer schools. Apart from this, this analysis held no real surprises.

\section{Regression analysis: School level}


Before turning to hierarchical linear modelling, it is instructive first to model performance at the school level, since this will provide information for the HLM. Table 8 shows two regressions each dealing with reading and mathematics performance of schools respectively. As can be seen, most of the regressors entering the final model were the school level equivalents (or averages) of the regressions for the individual models. The difference between the two models for each outcome lay in the choice of the maternal education variable, i.e. whether to use the percentage with matric or those with a degree. Both variables were significant in all the models, but they influenced the significance of the percentage of overage children in the reading model and of the percentage of male children in the mathematics model, pointing to some multi-collinearity. Interesting features of the results were the strong impact of the proportion of underage children, which came through with a much larger coefficient than that for the proportion of overage children. This was surprising in light of the result that the overage dummy played such a large role in the individual level models. The proportion of a school's pupils that were male had a strong negative consequence for marks, particularly those for reading. Whilst having an own textbook or sharing it with one other provided similar benefits in terms of reading scores, a shared textbook - even if it was shared with only one other - did not bring equivalently good results in mathematics. School equipment, but not school building, played a significant positive role in school performance. Urban location had strong positive effects. Surprisingly, mean school SES did not show a significant impact for mathematics and its impact for reading was not large either 5 . This lack of significance may have been the result of multicollinearity with mother's education, urbanization, repetition, and equipment. All of these variables were greater at the school than the individual level, possibly influencing the stability of results.

\section{Regression analysis: Hierarchical linear modelling}

Hierarchical linear models are designed to model situations such as the nesting of pupils within schools. This technique offers benefits beyond OLS since it allows researchers better to "pose hypotheses about relationships occurring at each level and across levels and also assess the amount of variation at each level” (Raudenbush \& Bryk 2002: 5). In particular, by making possible the modelling of random effects, an HLM model allows modelling of outcomes in which the effects of individual schools on pupil outcomes - in terms of both the intercepts and the slopes of the estimating equations - can vary. HLM modelling permits at

\footnotetext{
${ }^{5}$ It should be remembered here that the SES variable had a range of only 8 , which meant that scores would have differed only by about 67 marks between poorest and richest schools on account of SES alone.
} 
least a partial allowance for individual regressions for different schools with respect to some school level variables.

The hierarchical linear models used here were structured with individuals as level 1 and schools as level 2, with the dependent variable being individual scores. The level 1 model was very similar to the models employed above in the individual OLS regressions. For level 2, however, HLM allowed some of the individual effects influenced by school level factors. For example, if one were to hypothesize that the influence of home background (as proxied by books at home) was constrained by school resources as proxied by school equipment, it would have been possible to model the effect of having books at home being influenced by school equipment, and then to test whether such a model was appropriate. Furthermore, it was also possible to allow for the effect of individual schools on this relationship to differ between schools (i.e. to have a random effect) by specifying that this sub-model should have its own error term across schools.

The model employed for explaining reading scores was the following (the model for mathematics was very similar, except that in some cases other level 1 variables were found to provide a better fit):

\section{Level 1:}

Score $=\beta_{0}+\beta_{1} *$ Over12 $+\beta_{2} *$ Male $+\beta_{3} *$ EnglishSometimes $+\beta_{4}$ *EnglishAlways + $\beta_{5} *$ Livedwithparents $+\beta_{6} *$ AbsentFeesUnpaid $+\beta_{7} *$ SES $+\beta_{8} *$ Book11plus $+\beta_{9} *$ Repeat $1+$ $\beta_{10}$ *Repeat2 $+\beta_{11}$ *Repeat3 $+\beta_{12}$ *Homewk2 $+\beta_{13} *$ Homewk3 $+\beta_{14}$ *Notextbk + $\beta_{15} *$ MotherMatric $+\beta_{16} * \mathrm{FS}+\beta_{17} * \mathrm{GAU}+\beta_{18} * \mathrm{KZN}+\beta_{19} * \mathrm{LIM}+\beta_{20} * \mathrm{MPU}+\beta_{21} * \mathrm{NC}+$ $\beta_{22} * \mathrm{EC}+\beta_{23} * \mathrm{WC}+\mathrm{R}$

\section{Level 2:}

All individual level regressors were assumed to be unaffected by school level factors and to have fixed effects, except for the following:

$$
\begin{aligned}
& \beta_{0}=\gamma_{00}+\gamma_{01} *(\text { MeanSES })+U_{0} \\
& \beta 7=\gamma_{70}+\gamma_{71} *(\text { MeanSES })+U 7
\end{aligned}
$$

This model essentially is one in which the intercept and the slope of the SES variable at level 1 were modelled as outcomes of a level 2 (school level) variable, i.e. the mean school SES. Rewriting and rearranging the above equations produced the final mixed model:

Score $=\gamma_{00}+\gamma_{01} *$ MeanSES $+\beta_{1} *$ Over12 $+\beta_{2} *$ Male $+\beta_{3} *$ EnglishSometimes + $\beta_{4}{ }^{*}$ EnglishAlways $+\beta_{5}{ }^{*}$ Livedwithparents $+\beta_{6} *$ AbentFeesUnpaid $+\gamma_{70} *$ SES + $\gamma_{71} *$ SES*MeanSES $+\beta_{8} *$ Book11plus $+\beta_{9} *$ Repeat $1+\beta_{10} *$ Repeat $2+\beta_{11} *$ Repeat $3+$ 
$\beta_{12} *$ Homewk $2+\beta_{13} *$ Homewk $3+\beta_{14} *$ Notextbk $+\beta_{15} *$ MotherMatric $+\beta_{16} * \mathrm{FS}+\beta_{17} * \mathrm{GAU}+$ $\beta_{18} * \mathrm{KZN}+\beta_{19} * \mathrm{LIM}+\beta_{20} * \mathrm{MPU}+\beta_{21} * \mathrm{NC}+\beta_{22} * \mathrm{EC}+\beta_{23} * \mathrm{WC}+\mathrm{U}_{0}+\mathrm{U}_{7}+\mathrm{R}$

Where:

Over12 = dummy indicating pupil age was greater than 12

EnglishSometimes = dummy indicating pupils sometimes spoke English at home

EnglishAlways = dummy indicating pupil always spoke English at home

Livedwithparents $=$ dummy indicating pupil lived with parents

AbentFeesUnpaid = dummy indicating that pupil had been absent because school fees were unpaid

$\mathrm{SES}=$ individual level socio-economic status indicator

MeanSES $=$ mean socio-economic status at school level

Book11plus $=$ home contained more than 10 books

Repeat $1 /$ Repeat $2 /$ Repeat $3=$ had repeated one/two/three or more times respectively

Homewk2 = pupil reported doing homework at least twice a week

Homewk3 = pupil reported doing homework's most days of the week

Notextbk = had no textbook, or shared with more than 1 other

MotherMatric $=$ mother had matriculated

FS/GAU/KZN/LIM/MPU/NC/EC/WC = provincial dummies (NorthWest was the reference province)

$\mathrm{U}_{0}, \mathrm{U}_{7}, \mathrm{R}=$ error terms (random effects)

The models fitted are shown in Table 9 and Table 10. All the variables were entered uncentered and observations were weighted at both the individual and the school level (unweighted models showed only slightly modified results, though the basic model structure remained unchanged). Where some variable values were absent for any values from a particular school, all observations for the school were dropped. This reduced the sample somewhat.

The results for the reading score model showed that most of the variables found significant at the individual level did indeed play a role, though surprisingly the frequency of homework did play a significant positive role here, unlike in the full sample OLS regressions. The main differences between the reading and mathematics models lay in homework and textbook availability not entering the mathematics model.

The interesting part of the HLM model, however, lay in the modelling of the school level effects. It was found that mean school SES affected the intercept positively, i.e. richer schools performed better, ceteris paribus. But, perhaps more importantly, modelling the 
factors contributing to the role of SES on reading scores showed that school mean SES again had a positive influence. Put differently, individual SES and school level SES interacted positively to produce improved scores. How should this finding be interpreted? A simple explanation may be that school mean SES was a proxy for peer effects that operated to produce enhanced educational outcomes. However, a superior school level predictor would then have been the average reading score in the school. This variable did not perform as well as school SES as a predictor of both the slope and the intercept. An alternative view might be that mean SES at the school level reflected the resources available to the school, but then again one would have expected school facilities potentially to be a better regressor than school mean SES. This was found not to be the case when testing this model. It cannot either be inferred that mean SES was simply a proxy for urban, which was also tested and rejected as an alternative level 2 regressor. A tentative conclusion was thus that school mean SES may be seen as proxy for all of the above.

An analysis of the random effects showed that the standard deviations were large, particularly for the mean SES model, i.e. that many schools deviate from the general pattern of relationships between the school mean SES and individual SES. If, following Raudenbush and Bryk (2002:78), the 95 per cent plausible value for the school SES slope may be considered to be the 95 per cent confidence interval of the school mean SES slope, then the latter ranged from 19.8 to -15.6 : a very wide range indeed. There was thus still wide divergence between schools in how well they transformed SES into reading outcomes. The same also applied for mathematics outcomes, with a 95 per cent plausible range even much larger at 35.5 to -30.7 .06 . Many schools indeed even had a negative slope on SES. Reliability estimates showed that there remained large variability in slopes between schools, despite the fact that empirical Bayesian models usually shrink coefficient estimates relative to OLS estimates of the school level regressions where the latter would have fitted poorly on account of small samples and limited variation in SES values within many schools (see Raudenbusch \& Bryk, 2002: 87, 88).

Variance decomposition showed that the variance of $\mathrm{U}_{0}$ on the reading score was reduced by 74.4 per cent, whilst variance was reduced by only 13.8 per cent compared to the unconditional model for the error term R. Variance reduction thus mainly occurred through decreasing variance between schools rather than within them. This was unsurprising in view of the persistence in homogeneity in school-level SES and other characteristics - an enduring feature of South African schools even long after the demise of apartheid - and given that variance between schools was exceedingly high to start off with. A similar situation applied to 
mathematics scores, where variance between schools declined by 69.9 per cent while that within schools dropped by only 6.1 per cent.

Figure 5 shows the interaction between individual SES and reading scores (similar to the socio-economic gradient used by Ross and Zuze (2004)) for three types of schools: poor schools, average schools, and rich schools. Here the mean SES values used for each category were the midpoints of the range of SES scores in respectively the poorest, middle and richest quintile of schools (see footnote to Table 2). These lines were derived from the model in Equation 4 and the HLM output in Table 9. In poor schools, not even high individual SES scores could generate a good reading score, as performance was weak throughout the spectrum. In average schools, performance varied more with individual level SES. However, in rich schools a strong benefit in terms of reading score arose for individuals with high SES. But even those few children with low SES in rich schools performed better than similar individuals in poor or average schools (although such individuals were scarce, due to barriers to entry in such schools, and the fact that the very poorest children were usually located in rural areas). At the average South African SES level of 0.00, rich schools considerably outperformed the other two groups. Attending an affluent school thus clearly yielded returns in terms of academic performance. The same broad picture also applied to mathematics scores, with the SES gradient for poor schools even being markedly negative.

\section{Conclusion}

This paper has demonstrated that socio-economic differentials in 2000 still played a major role in educational outcomes at the primary school level in South Africa. The SACMEQ data have made it possible to show - as had already been done earlier using matriculation data for the secondary school level - that the school system was not yet systematically able to overcome inherited socio-economic disadvantage, and poor schools least so. If one additionally considered that returns to education in the South African labour market appeared to be convex (i.e. that education's contribution to earnings rose strongly at higher levels of education), then differential school outcomes were likely to translate into large inequalities in labour market outcomes.

The similarity of these findings with those on matriculation data (and the even larger values of the intraclass correlation coefficient found here) suggested that policy interventions were required earlier rather than later in the education process, as this high level of betweenschool inequality arose before secondary school level. 
The surprising finding was that, outside of the richest schools, SES had only a mild impact on test scores, which were quite low in SACMEQ context over most of the SES spectrum. A threshold effect appeared to operate, holding back even children from the middle class from performing well if they were outside schools for the rich.

As the labour market consequences of educational backlogs may persist for the productive lifetime of present pupils, and into the next generation through the impact of parent education and SES on future learning outcomes, improved functioning of poor schools is essential and urgent. This study has shown that more resources did not necessarily or without qualification improve school performance, although some resources (e.g. equipment at the school) appeared to play a role. As in much of the educational production function literature, the message from this study appeared to be not that resources did not matter, but rather that resources mattered only conditionally. There was a relatively large divergence in the ability of schools to convert resources into outcomes, as was shown in the large standard deviations on the random effects in the HLM models.

For informed policy intervention, measurement at the school level is essential to identify schools that perform below expectations. Such measurement is also essential for improving accountability of schools to the community - a particularly important goal in poor communities - and of the education system to broader society. This SACMEQ data again illustrated the importance of testing, since regular testing at various levels of the school system could play an important role in informing policy and targeting interventions. 


\section{References:}

Anderson, Kermyt; Case, Anne; Lam, David. 2001. "Causes and consequences of schooling outcomes in South Africa: Evidence from survey data”. Social Dynamics, 27(1): pp. 37 59.

Case, Anne; Deaton, Angus. 1999. "School inputs and educational outcomes in South Africa." Quarterly Journal of Economics, 114, 1047-1084.

Crouch, Luis; Mabogoane, Thabo. 1998. "When the residuals matter more than the coefficients: An educational perspective." Studies in Economics and Econometrics, 22(2), $1-14$

Crouch, Luis; Mabogoane, Thabo. 2001. "No magic bullets, just tracer bullets: The role of learning resources, social advantage, and education management in improving the performance of South African schools." Social Dynamics, 27(1), 60-78.

Hanushek, Eric. 2002. Publicly provided education. (NBER Working Paper.) Cambridge, Mass.: National Bureau of Economic Research.

Lam, David. 1999. Generating extreme inequality: Schooling, earnings, and intergenerational transmission of human capital in South Africa and Brazil. (Research Report 99-439.) Ann Arbor: Population Studies Center, University of Michigan.

Raudenbush, Stephen W.; Bryk, Anthony S. 2002. Hierarchical linear models: Applications and data analysis methods. London: Sage Publications.

Raudenbush, Stephen W.; Bryk, Anthony S. Cheong, Yuk Fai; Congdon, Richard T. Jr. 2004 HLM6: Hierarchical linear and nonlinear modelling. Chicago: Scientific Software International.

Ross, Kenneth N; Saito, Mioko; Dolata, Stephanie; Ikeda, Miyako; Zuze, Linda; Murimba, Saul; Postlethwaite, T. Neville; Griffin, Patrick. 2005. The conduct of the SACMEQ II project. Ch. 2 of SACMEQ. 2005. Kenya SACMEQ II report. Harare: SACMEQ. Retrieved 1 July 2005 from http://www.sacmeq.org/links.htm

Ross, Kenneth N.; Zuze, Linda. 2004. Traditional and alternative views of school system performance. IIP newsletter October-December. Paris: International Institute for Educational Planning, 8-9.

Rumberger, Russell W. \& Gregory J. Palardy. 2003. Multilevel models for school effectiveness research. Draft chapter to appear in David Kaplan./ Handbook of Quantitative Methodology for the Social Sciences. Retrieved 1 July 2005 from http://www.education.ucsb.

edu/rumberger/internet\%20pages/Papers/Rumberger\%20and\%20Palardy-School $\% 20$ Effec

tiveness\%20chapter\%20version\%2016.doc

Postlethwaite, T. N. 2004. Monitoring educational achievement. Paris: International Institute for Educational Planning.

SACMEQ. 2004. The release of the SACMEQ data archive. 1 July. Harare: SACMEQ. Retrieved 1 July 2005 from: http://www.sacmeq.org/access/announce1.pdf

SACMEQ. 2005. Kenya SACMEQ II report. Harare: SACMEQ. Retrieved 1 July 2005 from http://www.sacmeq.org/links.htm

Taylor, Nick; Muller, Johan; Vinjevold Penny. 2003. Getting schools working: Research and systemic school reform in South Africa. Cape Town: Pearson Educational

Van der Berg, Servaas; Burger, Ronelle. 2002. Education and socio-economic differentials: A study of school performance in the Western Cape. South African Journal of Economics. $71(3), 496-522$. 
TABLE 1 - Intra-class correlation coefficient rho (proportion of variance at school level) from PIRLS and SACMEQ I \& II studies and from South African matric data set (arranged by rho for reading scores)

\begin{tabular}{|c|c|c|c|}
\hline Country or territory & Study & $\begin{array}{l}\text { Rho for } \\
\text { Reading }\end{array}$ & $\begin{array}{l}\text { Rho for } \\
\text { Maths }\end{array}$ \\
\hline Seychelles & SACMEQ II 2002 & 0.08 & 0.08 \\
\hline Iceland & PIRLS 2001 & 0.084 &.. \\
\hline Slovenia & PIRLS 2001 & 0.087 & .. \\
\hline Sweden & PIRLS 2001 & 0.087 & .. \\
\hline Norway & PIRLS 2001 & 0.096 & .. \\
\hline Cyprus & PIRLS 2001 & 0.105 & .. \\
\hline Turkey & PIRLS 2001 & 0.132 & .. \\
\hline Germany & PIRLS 2001 & 0.141 & .. \\
\hline Czech Republic & PIRLS 2001 & 0.157 & .. \\
\hline France & PIRLS 2001 & 0.161 & ... \\
\hline Zanzibar & SACMEQ I 1995 & 0.17 & .. \\
\hline Canada (Ontario, Quebec) & PIRLS 2001 & 0.174 & .. \\
\hline England & PIRLS 2001 & 0.179 & .. \\
\hline Scotland & PIRLS 2001 & 0.179 & .. \\
\hline Netherlands & PIRLS 2001 & 0.187 & .. \\
\hline Italy & PIRLS 2001 & 0.198 & .. \\
\hline Latvia & PIRLS 2001 & 0.213 & .. \\
\hline Lithuania & PIRLS 2001 & 0.214 & .. \\
\hline Greece & PIRLS 2001 & 0.221 & .. \\
\hline Hungary & PIRLS 2001 & 0.222 & .. \\
\hline Malawi & SACMEQ I 1995 & 0.24 & .. \\
\hline Slovak Republic & PIRLS 2001 & 0.249 & .. \\
\hline New Zealand & PIRLS 2001 & 0.25 & .. \\
\hline Mauritius & SACMEQ I 1995 & 0.25 & .. \\
\hline Zanzibar & SACMEQ II 2000 & 0.25 &.. \\
\hline Botswana & SACMEQ II 2000 & 0.26 & 0.22 \\
\hline Mauritius & SACMEQ II 2001 & 0.26 & 0.25 \\
\hline Zambia & SACMEQ I 1995 & 0.27 & .. \\
\hline Zimbabwe & SACMEQ I 1995 & 0.27 & .. \\
\hline Macedonia & PIRLS 2001 & 0.271 & .. \\
\hline Malawi & SACMEQ II 2002 & 0.29 & 0.15 \\
\hline Hong Kong & PIRLS 2001 & 0.295 &.. \\
\hline Mozambique & SACMEQ II 2000 & 0.30 & 0.21 \\
\hline Zambia & SACMEQ II 2000 & 0.32 & 0.22 \\
\hline SACMEQ Total ( across all countries) & SACMEQ I 1995 & 0.33 &.. \\
\hline Kuwait & PIRLS 2001 & 0.334 &.. \\
\hline Tanzania & SACMEQ II 2000 & 0.34 & 0.26 \\
\hline Bulgaria & PIRLS 2001 & 0.345 & .. \\
\hline Belize & PIRLS 2001 & 0.348 & ... \\
\hline Romania & PIRLS 2001 & 0.351 & .. \\
\hline Swaziland & SACMEQ II 2000 & 0.37 & 0.26 \\
\hline SACMEQ Total ( across all countries) & SACMEQ II 2000 & 0.37 & 0.32 \\
\hline Iran & PIRLS 2001 & 0.382 &.. \\
\hline Lesotho & SACMEQ II 2000 & 0.39 & 0.30 \\
\hline Moldova & PIRLS 2001 & 0.395 & .. \\
\hline South Africa & 2003 Matric aggregates & $0.399^{6}$ & $0.389^{7}$ \\
\hline
\end{tabular}

\footnotetext{
${ }^{6}$ Matric aggregate for all subjects
} 


\begin{tabular}{|l|l|c|c|}
\hline Israel & PIRLS 2001 & 0.415 & .. \\
\hline Argentina & PIRLS 2001 & 0.418 &.. \\
\hline Kenya & SACMEQ I 1995 & 0.42 & .. \\
\hline United States & PIRLS 2001 & 0.424 &.. \\
\hline Russian Federation & PIRLS 2001 & 0.447 &.. \\
\hline Kenya & SACMEQ II 2000 & 0.45 & 0.38 \\
\hline Colombia & PIRLS 2001 & 0.459 &.. \\
\hline Morocco & PIRLS 2001 & 0.554 &.. \\
\hline Uganda & SACMEQ II 2000 & 0.57 & 0.65 \\
\hline Singapore & PIRLS 2001 & 0.586 &.. \\
\hline Namibia & SACMEQ II 2000 & 0.60 & 0.53 \\
\hline Namibia & SACMEQ I 1995 & 0.65 &.. \\
\hline South Africa & SACMEQ II 2000 & $\mathbf{0 . 7 0}$ & $\mathbf{0 . 6 4}$ \\
\hline South Africa: Poorest 90\% of schools & SACMEQ II 2000 & $\mathbf{0 . 5 7 7}$ & $\mathbf{0 . 5 0 0}$ \\
\hline South Africa: Poorest 80\% of schools & SACMEQ II 2000 & $\mathbf{0 . 4 6 6}$ & $\mathbf{0 . 3 8 9}$ \\
\hline
\end{tabular}

Source: Postlethwaite, 2004: Tables 3.6 and 3.7; South African matric data calculated from National Department

of Education data set

\footnotetext{
${ }^{7}$ Mathematics mark for those who took Maths. Higher grade mark converted to standard grade equivalent by adding 10 percentage points.
} 
TABLE 2: Distribution of pupil performance across school quintiles by mean SES of schools

\begin{tabular}{|c|c|c|c|c|}
\hline $\begin{array}{l}\text { School SES } \\
\text { Quintile }\end{array}$ & Mean & Std. Dev. & $\begin{array}{l}\text { \% with mark } \\
\text { above } 500\end{array}$ & $\begin{array}{l}\text { \% with mark } \\
\text { below } 400\end{array}$ \\
\hline \multicolumn{5}{|c|}{ Pupil Reading Test Score } \\
\hline Quintile 1 & 423.75 & 76.40 & $13.56 \%$ & $37.32 \%$ \\
\hline Quintile 2 & 422.54 & 67.04 & $10.19 \%$ & $33.34 \%$ \\
\hline Quintile 3 & 450.27 & 73.13 & $19.97 \%$ & $23.21 \%$ \\
\hline Quintile 4 & 494.59 & 95.36 & $42.15 \%$ & $12.45 \%$ \\
\hline Quintile 5 & 626.11 & 118.55 & $82.45 \%$ & $2.31 \%$ \\
\hline Total & 492.26 & 122.36 & $36.73 \%$ & $20.91 \%$ \\
\hline \multicolumn{5}{|c|}{ Pupil Maths Test Score } \\
\hline Quintile 1 & 441.49 & 67.01 & $19.94 \%$ & $21.54 \%$ \\
\hline Quintile 2 & 437.44 & 63.45 & $14.66 \%$ & $25.31 \%$ \\
\hline Quintile 3 & 441.45 & 61.93 & $15.80 \%$ & $21.80 \%$ \\
\hline Quintile 4 & 475.16 & 84.79 & $33.73 \%$ & $14.90 \%$ \\
\hline Quintile 5 & 594.18 & 125.52 & $76.36 \%$ & $4.73 \%$ \\
\hline Total & 486.15 & 109.06 & $35.21 \%$ & $16.76 \%$ \\
\hline \multicolumn{5}{|l|}{ Note: } \\
\hline Quintile 1 & \multirow{2}{*}{\multicolumn{3}{|c|}{$\begin{array}{l}-3.8901<\text { School Mean SES }<-1.6223 \\
-1.5868<\text { School Mean SES }<-0.5330\end{array}$}} & (34 schools) \\
\hline Quintile 2 & & & & (34 schools) \\
\hline Quintile 3 & \multicolumn{3}{|c|}{$-0.5313<$ School Mean SES $<0.4429$} & (33 schools) \\
\hline Quintile 4 & \multicolumn{3}{|c|}{$0.4677<$ School Mean SES $<1.4239$} & (34 schools) \\
\hline Quintile 5 & \multirow{2}{*}{\multicolumn{3}{|c|}{$\begin{array}{l}1.4517<\text { School Mean SES }<3.4141 \\
-3.890110<\text { SchoolSE } S<3.414095\end{array}$}} & (34 schools) \\
\hline Total & & & & (169 schools) \\
\hline
\end{tabular}


Table 3: Description of variables used

\begin{tabular}{|c|c|c|c|c|c|}
\hline Variable & Description & Mean. & $\begin{array}{l}\text { Std } \\
\text { Dev. }\end{array}$ & Min. & Max. \\
\hline lanscore & $\begin{array}{l}\text { Pupil reading test score [SACMEQ mean } \\
=500, \text { s.d. }=100]\end{array}$ & 484.70 & 117.50 & 5.72 & 1061.84 \\
\hline matscore & $\begin{array}{l}\text { Pupil maths test score [SACMEQ mean }= \\
500, \text { s.d. }=100]\end{array}$ & 479.10 & 107.38 & 0.43 & 1065.30 \\
\hline \multicolumn{6}{|l|}{ PUPIL } \\
\hline age & Age of pupil (in years) & 12.804 & 1.614 & 10 & 25 \\
\hline gender & Gender of pupils & 0.488 & 0.500 & 0 & 1 \\
\hline under12 & Under 12 & 0.190 & 0.392 & 0 & 1 \\
\hline over12 & Over 12 & 0.478 & 0.500 & 0 & 1 \\
\hline always & $\begin{array}{l}\text { Pupil most of the time spoke English } \\
\text { outside school }\end{array}$ & 0.136 & 0.342 & 0 & 1 \\
\hline sometimes & $\begin{array}{l}\text { Pupil sometimes spoke English outside } \\
\text { school }\end{array}$ & 0.624 & 0.484 & 0 & 1 \\
\hline tuition (Reading) & Extra tuition lessons outside school & 0.303 & 0.460 & 0 & 1 \\
\hline tuition (Maths) & Extra tuition lessons outside school & 0.315 & 0.464 & 0 & 1 \\
\hline neverrepeat & $\%$ of pupils who never repeated a grade & 0.563 & 0.216 & 0.11 & 1 \\
\hline repeat1 & Repeated once & 0.285 & 0.451 & 0 & 1 \\
\hline repeat2 & Repeated twice & 0.094 & 0.292 & 0 & 1 \\
\hline repeat3 & Repeated three times or more & 0.058 & 0.234 & 0 & 1 \\
\hline livedwithparents & Lived with parents & 0.783 & 0.412 & 0 & 1 \\
\hline absent & $\begin{array}{l}\text { Number of days absent from school per } \\
\text { month }\end{array}$ & 1.604 & 2.804 & 0 & 26 \\
\hline \multicolumn{6}{|l|}{ FAMILY } \\
\hline SES & Socio-economic status variable & 00 & 2.272 & -4.70 & 4.01 \\
\hline urban & School location: urban ( large town) & 0.281 & 0.450 & 0 & 1 \\
\hline location1 & School location - small town & 0.273 & 0.445 & 0 & 1 \\
\hline mothermatric & Mother had at least matric & 0.309 & 0.462 & 0 & 1 \\
\hline mothertdegree & Mother had degree & 0.085 & 0.279 & 0 & 1 \\
\hline fathermatric & Father had at least matric & 0.316 & 0.199 & 0 & 0.90 \\
\hline fatherdegree & Father had degree & 0.112 & 0.315 & 0 & 1 \\
\hline book1 & $1-10$ books & 0.466 & 0.499 & 0 & 1 \\
\hline book2 & $11-50$ books & 0.187 & 0.390 & 0 & 1 \\
\hline book3 & $51-100$ books & 0.066 & 0.248 & 0 & 1 \\
\hline book4 & $101-200$ books & 0.033 & 0.178 & 0 & 1 \\
\hline book5 & $201+$ books & 0.055 & 0.228 & 0 & 1 \\
\hline schoolfeeUnpaid & Reason for absence - school fee not paid & 0.030 & 0.172 & 0 & 1 \\
\hline lightsource & Electric light at home & 0.675 & 0.469 & 0 & 1 \\
\hline \multicolumn{6}{|l|}{ SCHOOL } \\
\hline \multicolumn{6}{|l|}{ School resources } \\
\hline ptratio & Pupil-Teacher ratio & 35.466 & 6.614 & 12 & 57.43 \\
\hline pupilperclass & Number of pupils per Grade 6 class & 42.230 & 12.039 & 17 & 98 \\
\hline classsize & Class Size & 41.319 & 11.812 & 4 & 82 \\
\hline building & School facility - building & 2.723 & 1.866 & 0 & 6 \\
\hline equipment & School facility - equipment & 5.307 & 3.889 & 0 & 11 \\
\hline resource & Classroom Resources - Index & 5.962 & 1.707 & 0 & 8 \\
\hline notextbook (Reading) & No textbook, or shared with two or more & 0.339 & 0.473 & 0 & 1 \\
\hline notextbook (Maths) & No textbook, or shared with two or more & 0.407 & 0.491 & 0 & 1 \\
\hline ownbook (Reading) & Had own textbook & 0.471 & 0.499 & 0 & 1 \\
\hline ownbook (Maths) & Had own textbook & 0.428 & 0.495 & 0 & 1 \\
\hline sharedwithone & Shared textbook with one pupil & 0.190 & 0.219 & 0 & 1 \\
\hline
\end{tabular}




\begin{tabular}{|c|c|c|c|c|c|}
\hline (Reading) & & & & & \\
\hline sharedwithone (Maths) & Shares textbook with one pupil & 0.165 & 0.371 & 0 & 1 \\
\hline borrow & Library: available; can take out books & 0.280 & 0.449 & 0 & 1 \\
\hline \multicolumn{6}{|l|}{ School processes } \\
\hline correct (Reading) & $\begin{array}{l}\text { Reading homework corrected? (1:Always, } \\
0 \text { : Sometimes or never) }\end{array}$ & 0.521 & 0.500 & 0 & 1 \\
\hline correct (Maths) & $\begin{array}{l}\text { Reading homework corrected? (1:Always, } \\
\text { 0: Sometimes or never) }\end{array}$ & 0.671 & 0.470 & 0 & 1 \\
\hline homework1 (Reading) & Homework once per month & 0.179 & 0.383 & 0 & 1 \\
\hline homework1 (Maths) & Homework once per month & 0.102 & 0.303 & 0 & 1 \\
\hline homework2 (Reading) & Homework once per week & 0.305 & 0.461 & 0 & 1 \\
\hline homework2 (Maths) & Homework once per week & 0.336 & 0.473 & 0 & 1 \\
\hline homework3 (Reading) & Homework most days of the week & & & & \\
\hline homework3 (Maths) & Homework most days of the week & 0.524 & 0.500 & 0 & 1 \\
\hline $\begin{array}{l}\text { testfrequency } \\
\text { (Reading) }\end{array}$ & Frequency of tests & 3.996 & 0.922 & 0 & 5 \\
\hline testfrequency (Maths) & Frequency of tests & 3.777 & 0.744 & 2 & 5 \\
\hline inspector & Number of visits by Inspectors in 2000 & 0.433 & 1.233 & 0 & 10 \\
\hline community & Community contributions & 5.063 & 3.054 & 0 & 14 \\
\hline \multicolumn{6}{|l|}{ School teacher } \\
\hline stage (Reading) & Teacher's age (in years) & 38.55 & 8.128 & 24 & 64 \\
\hline stage (Maths) & Teacher's age (in years) & 38.21 & 7.040 & 25 & 55 \\
\hline stgender (Reading) & Male teacher & 0.444 & 0.498 & 0 & 1 \\
\hline stgender (Maths) & Male teacher & 0.483 & 0.501 & 0 & 1 \\
\hline $\begin{array}{l}\text { stteachinghours } \\
\text { (Reading) }\end{array}$ & Teacher's teaching hours per week & 20.539 & 9.374 & 3 & 50 \\
\hline $\begin{array}{l}\text { stteachinghours } \\
\text { (Maths) }\end{array}$ & Teacher's teaching hours per week & 20.515 & 8.378 & 3 & 45 \\
\hline sttertiary (Reading) & Teacher has tertiary education & 0.222 & 0.417 & 0 & 1 \\
\hline sttertiary (Maths) & Teacher has tertiary education & 0.261 & 0.441 & 0 & 1 \\
\hline sttraining (Reading) & Teachers' training - Index & 3.150 & 0.862 & 0 & 4 \\
\hline sttraining (Maths) & Teachers' training - Index & 3.172 & 0.811 & 0 & 4 \\
\hline \multicolumn{6}{|l|}{ School principal } \\
\hline shage & Principal's age (in years) & 46.186 & 6.471 & 31 & 61 \\
\hline shgender & Male principal & 0.788 & 0.408 & 0 & 1 \\
\hline shteachinghours & Principal's teaching hours per week & 8.307 & 6.806 & 0 & 35 \\
\hline shtertiary & Principal's education: tertiary & 0.445 & 0.497 & 0 & 1 \\
\hline shtraining & Principal's training - Index & 3.351 & 0.788 & 0.50 & 4 \\
\hline \multicolumn{6}{|l|}{ School: Other } \\
\hline classproblem & Classroom problems & 4.385 & 1.717 & 0 & 8 \\
\hline pupilproblem & Pupils' behaviour problems & 13.746 & 5.986 & 3 & 36 \\
\hline teacherproblem & Teachers' behaviour problems & 4.406 & 3.390 & 0 & 20 \\
\hline \multicolumn{6}{|l|}{ PROVINCES } \\
\hline $\mathrm{EC}$ & Eastern Cape & 0.156 & 0.363 & 0 & 1 \\
\hline FS & Free State & 0.088 & 0.283 & 0 & 1 \\
\hline GAU & Gauteng & 0.112 & 0.315 & 0 & 1 \\
\hline KZN & KwaZulu-Natal & 0.154 & 0.361 & 0 & 1 \\
\hline LIM & Limpopo & 0.140 & 0.347 & 0 & 1 \\
\hline MPU & Mpumalanga & 0.090 & 0.286 & 0 & 1 \\
\hline $\mathrm{NC}$ & Northern Cape & 0.083 & 0.275 & 0 & 1 \\
\hline NW & North West & 0.093 & 0.290 & 0 & 1 \\
\hline $\mathrm{WC}$ & Western Cape & 0.085 & 0.279 & 0 & 1 \\
\hline
\end{tabular}


Table 4: OLS regression models of SCAMEQ reading and mathematics test scores, for full and reduced sample

\begin{tabular}{|c|c|c|c|c|}
\hline \multirow[b]{2}{*}{ Dependent variable: } & \multicolumn{2}{|c|}{ Full sample } & \multicolumn{2}{|c|}{$\begin{array}{l}\text { Excluding richest } 20 \% \text { of } \\
\text { schools }\end{array}$} \\
\hline & $\begin{array}{l}\text { Reading } \\
\text { score }\end{array}$ & $\begin{array}{l}\text { Mathematics } \\
\text { score }\end{array}$ & $\begin{array}{l}\text { Reading } \\
\text { score }\end{array}$ & $\begin{array}{l}\text { Mathematics } \\
\text { score }\end{array}$ \\
\hline \multirow[t]{2}{*}{ Underage (under 12) } & & -12.595 & & \\
\hline & & $(2.21)^{*}$ & & \\
\hline \multirow[t]{2}{*}{ Overage (over 12) } & -21.026 & -20.641 & -16.446 & -9.284 \\
\hline & $(5.46) * *$ & $(6.24)^{* *}$ & $(4.44)^{* *}$ & $(2.94)^{* *}$ \\
\hline \multirow[t]{2}{*}{ Male } & -12.656 & 3.824 & -9.818 & 3.273 \\
\hline & $(4.04)^{* *}$ & $(1.24)$ & $(2.91)^{* *}$ & $(1.11)$ \\
\hline \multirow[t]{2}{*}{ Sometimes spoke English at home } & 19.016 & 14.781 & 23.064 & 19.178 \\
\hline & $(4.16)^{* *}$ & $(3.13)^{* *}$ & $(4.99)^{* *}$ & $(3.91)^{* *}$ \\
\hline \multirow[t]{2}{*}{ Always spoke English at home } & 26.590 & 24.002 & 15.235 & 14.526 \\
\hline & $(3.43)^{* *}$ & $(3.25) * *$ & $(1.96)^{*}$ & $(2.23)^{*}$ \\
\hline \multirow[t]{2}{*}{ Lived with parents } & 16.217 & 13.971 & 11.999 & 11.665 \\
\hline & $(3.46)^{* *}$ & $(2.78)^{* *}$ & $(2.95)^{* *}$ & $(2.99)^{* *}$ \\
\hline \multirow[t]{2}{*}{ Has more than 10 books at home } & 12.226 & 16.105 & & \\
\hline & $(3.11)^{* *}$ & $(4.31)^{* *}$ & & \\
\hline \multirow[t]{2}{*}{ No of days absent per month } & -1.759 & -2.832 & -1.756 & -2.045 \\
\hline & $(2.29)^{*}$ & $(3.08)^{* *}$ & $(2.82)^{* *}$ & $(2.79)^{* *}$ \\
\hline \multirow[t]{2}{*}{ Absent because school fee not paid } & -16.391 & & -11.251 & \\
\hline & $(2.15)^{*}$ & & $(1.66)$ & \\
\hline \multirow[t]{2}{*}{ Repeated once } & -24.040 & -19.691 & -16.796 & -12.237 \\
\hline & $(5.81)^{* *}$ & $(5.01)^{* *}$ & $(3.61)^{* *}$ & $(3.24)^{* *}$ \\
\hline \multirow[t]{2}{*}{ Repeated twice } & -30.198 & -16.094 & -26.040 & -12.865 \\
\hline & $(5.36)^{* *}$ & $(2.50)^{*}$ & $(4.53)^{* *}$ & $(1.95)$ \\
\hline \multirow[t]{2}{*}{ Repeated three times or more } & -39.833 & -36.831 & -28.184 & -27.427 \\
\hline & $(6.59)^{* *}$ & $(5.79)^{* *}$ & $(4.73)^{* *}$ & $(4.60)^{* *}$ \\
\hline \multirow[t]{2}{*}{ Mother at least matric } & 11.394 & & & \\
\hline & $(2.45)^{*}$ & & & \\
\hline \multirow[t]{2}{*}{ Mother degree } & & 16.082 & 17.616 & 14.115 \\
\hline & & $(2.44)^{*}$ & $(2.29)^{*}$ & $(1.79)$ \\
\hline \multirow[t]{2}{*}{ Homework once per month } & & & 27.653 & \\
\hline & & & $(3.17)^{* *}$ & \\
\hline \multirow[t]{2}{*}{ Homework once per week } & & & 38.729 & \\
\hline & & & $(5.08)^{* *}$ & \\
\hline \multirow[t]{2}{*}{ Homework most days of the week } & & & 33.363 & \\
\hline & & & $(5.18)^{* *}$ & \\
\hline \multirow[t]{2}{*}{ SES } & 6.148 & 4.028 & 3.312 & 2.147 \\
\hline & $(4.44) * *$ & $(2.81)^{* *}$ & $(2.68)^{* *}$ & $(1.42)$ \\
\hline \multirow[t]{2}{*}{ SES squared } & 1.365 & 2.093 & & \\
\hline & $(2.78)^{* *}$ & $(3.70) * *$ & & \\
\hline \multirow[t]{2}{*}{ Urban } & 41.782 & 36.093 & 35.554 & \\
\hline & $(3.63)^{* *}$ & $(2.75)^{* *}$ & $(3.09)^{* *}$ & \\
\hline \multirow[t]{2}{*}{ No textbook, or shared with more than 1} & -13.280 & & -13.382 & \\
\hline & $(2.85)^{* *}$ & & $(2.99)^{* *}$ & \\
\hline School building & 9.014 & 11.521 & & \\
\hline
\end{tabular}




\begin{tabular}{|l|c|c|c|c|}
\hline & $(2.31)^{*}$ & $(3.05)^{* *}$ & & \\
\hline School equipment & 7.704 & 4.377 & 5.640 & \\
\hline EC & $(4.30)^{* *}$ & $(2.47)^{*}$ & $(3.05)^{* *}$ & \\
\hline & 38.479 & 38.733 & 37.077 & 32.072 \\
\hline FS & $(2.33)^{*}$ & $(2.47)^{*}$ & $(2.65)^{* *}$ & $(2.64)^{* *}$ \\
\hline & -34.160 & -26.553 & -11.708 & 30.603 \\
\hline GAU & $(1.90)$ & $(1.38)$ & $(0.70)$ & $(2.75)^{* *}$ \\
\hline & 31.589 & 28.782 & 42.270 & 46.056 \\
\hline KZN & $(1.58)$ & $(1.49)$ & $(2.56)^{*}$ & $(3.95)^{* *}$ \\
\hline & 56.081 & 54.460 & 57.620 & 73.311 \\
\hline LIM & $(3.21)^{* *}$ & $(3.06)^{* *}$ & $(3.54)^{* *}$ & $(3.75)^{* *}$ \\
\hline & 41.946 & 48.061 & 26.913 & 23.322 \\
\hline MPU & $(2.41)^{*}$ & $(2.79)^{* *}$ & $(2.00)^{*}$ & $(2.00)^{*}$ \\
\hline & 15.747 & 17.391 & 19.969 & 23.716 \\
\hline NC & $(1.07)$ & $(1.20)$ & $(1.47)$ & $(1.71)$ \\
\hline & -10.127 & -3.800 & 17.965 & 46.011 \\
\hline WC & $(0.56)$ & $(0.22)$ & $(1.00)$ & $(3.62)^{* *}$ \\
\hline & 60.113 & 53.055 & 85.427 & 89.258 \\
\hline Constant & $(2.99)^{* *}$ & $(2.35)^{*}$ & $(3.77)^{* *}$ & $(3.59)^{* *}$ \\
\hline & 372.531 & 367.479 & 365.727 & 405.452 \\
\hline Observations & $(23.82)^{* *}$ & $(25.43)^{* *}$ & $(23.40)^{* *}$ & $(36.19)^{* *}$ \\
\hline R-squared & 3139 & 3113 & 2492 & 2493 \\
\hline Absut & 0.62 & 0.52 & 0.34 & 0.18 \\
\hline
\end{tabular}

Absolute value of $t$ statistics in parentheses, taking account of clustering effects and using Huber-White robust standard errors to deal with possible heteroskedasticity.

* significant at 5\% level

** significant at $1 \%$ level 
Table 5: Effect of sample reduction on scores: Observations at school levels

\begin{tabular}{|l|l|c|c|c|c|c|}
\hline & Score for: & $\begin{array}{c}\text { Observations } \\
\text { (schools) }\end{array}$ & Mean & $\begin{array}{c}\text { Std. } \\
\text { Dev. }\end{array}$ & Min & Max \\
\hline Full sample & Reading & 169 & 483.3 & 96.9 & 302.8 & 809.0 \\
\hline Bottom 90\% by SES & Reading & 152 & 461.9 & 73.9 & 302.8 & 688.6 \\
\hline Bottom $80 \%$ by SES & Reading & 135 & 447.5 & 57.8 & 302.8 & 626.1 \\
\hline Full sample & Mathematics & 169 & 478.0 & 86.0 & 351.7 & 832.6 \\
\hline Bottom 90\% by SES & Mathematics & 152 & 457.5 & 58.1 & 351.7 & 719.2 \\
\hline Bottom $80 \%$ by SES & Mathematics & 135 & 447.0 & 43.8 & 351.7 & 643.9 \\
\hline
\end{tabular}


Table 6: Effect of sample reduction on some coefficients in basic regression models for reading and mathematics

\begin{tabular}{|l|c|c|c|c|c|c|}
\hline & \multicolumn{3}{|c|}{ Reading score } & \multicolumn{3}{c|}{ Mathematics score } \\
\hline & $\begin{array}{c}\text { Full } \\
\text { sample }\end{array}$ & $\begin{array}{c}\text { Excluding } \\
\text { richest 10\% } \\
\text { of schools }\end{array}$ & $\begin{array}{c}\text { Excluding } \\
\text { richest 20\% } \\
\text { of schools }\end{array}$ & $\begin{array}{c}\text { Full } \\
\text { sample }\end{array}$ & $\begin{array}{c}\text { Excluding } \\
\text { richest 10\% } \\
\text { of schools }\end{array}$ & $\begin{array}{c}\text { Excluding } \\
\text { richest 20\% } \\
\text { of schools }\end{array}$ \\
\hline SES & 9.022 & 6.883 & 3.991 & 6.295 & 2.996 & 0.602 \\
\hline & $(6.91)^{* *}$ & $(5.02)^{* *}$ & $(3.35)^{* *}$ & $(4.31)^{* *}$ & $(2.22)^{*}$ & $(0.58)$ \\
\hline Urban & 52.002 & 44.325 & 35.866 & 47.272 & 33.969 & 29.672 \\
\hline & $(3.41)^{* *}$ & $(2.46)^{*}$ & $(2.41)^{*}$ & $(3.02)^{* *}$ & $(1.86)$ & $(1.39)$ \\
\hline School equipment & 9.503 & 8.764 & 5.394 & 6.804 & 5.386 & 1.821 \\
\hline & $(6.82)^{* *}$ & $(5.48)^{* *}$ & $(4.13)^{* *}$ & $(5.13)^{* *}$ & $(3.81)^{* *}$ & $(1.78)$ \\
\hline Observations & 3139 & 2805 & 2492 & 3113 & 2780 & 2471 \\
\hline & 0.55 & 0.45 & 0.25 & 0.42 & 0.29 & 0.11 \\
\hline
\end{tabular}

Note: Other variables included as controls were gender of pupil, overage, English spoken at home (always and sometimes separately), absence due to school fees not paid, repeated (1,2 or more years separately), and whether the pupils lived with parents

Absolute value of $t$ statistics in parentheses, taking account of clustering effects and using Huber-White robust standard errors to deal with possible heteroskedasticity.

* significant at 5\% level

** significant at $1 \%$ level 
Table 7: Quantile regressions of reading and mathematics scores at median and 80th percentile

\begin{tabular}{|c|c|c|c|c|}
\hline & At median & $\begin{array}{c}\text { At } 80^{\text {th }} \\
\text { percentile }\end{array}$ & At median & $\begin{array}{c}\text { At } 8^{\text {th }} \\
\text { percentile }\end{array}$ \\
\hline & Reading & Mathematics & Reading & Mathematics \\
\hline \multirow[t]{2}{*}{ Overage (Over 12) } & -25.476 & -30.298 & -17.254 & -17.585 \\
\hline & $(7.44)^{* *}$ & $(7.07)^{* *}$ & $(5.75)^{* *}$ & $(4.71)^{* *}$ \\
\hline \multirow[t]{2}{*}{ Male } & -8.985 & -11.478 & 0.996 & 3.806 \\
\hline & $(3.00)^{* *}$ & $(2.98)^{* *}$ & $(0.38)$ & $(1.14)$ \\
\hline \multirow[t]{2}{*}{ Sometimes spoke English at home } & 20.638 & 29.379 & 18.245 & 18.37 \\
\hline & $(5.67)^{* *}$ & $(6.36)^{* *}$ & $(5.72)^{* *}$ & $(4.58)^{* *}$ \\
\hline \multirow[t]{2}{*}{ Always spoke English at home } & 27.367 & 46.548 & 23.801 & 36.868 \\
\hline & $(5.17)^{* *}$ & $(7.19)^{* *}$ & $(5.13)^{* *}$ & $(6.53)^{* *}$ \\
\hline \multirow[t]{2}{*}{ Lived with parents } & 12.735 & 15.689 & 3.351 & 10.684 \\
\hline & $(3.46)^{* *}$ & $(3.34)^{* *}$ & $(1.04)$ & $(2.62)^{* *}$ \\
\hline \multirow[t]{2}{*}{ Repeated once } & -21.186 & -29.67 & -17.687 & -23.314 \\
\hline & $(5.77)^{* *}$ & $(6.46)^{* *}$ & $(5.49) * *$ & $(5.87)^{* *}$ \\
\hline \multirow[t]{2}{*}{ Repeated twice } & -21.466 & -37.672 & -18.515 & -23.761 \\
\hline & $(3.88)^{* *}$ & $(5.44)^{* *}$ & $(3.80)^{* *}$ & $(3.93)^{* *}$ \\
\hline \multirow[t]{2}{*}{ Repeated three times or more } & -19.346 & -43.465 & -28.809 & -27.531 \\
\hline & $(2.92)^{* *}$ & $(5.24)^{* *}$ & $(4.93)^{* *}$ & $(3.70)^{* *}$ \\
\hline \multirow[t]{2}{*}{ SES } & 6.209 & 7.439 & 3.638 & 3.496 \\
\hline & $(7.82)^{* *}$ & $(7.44)^{* *}$ & $(5.23)^{* *}$ & $(4.11)^{* *}$ \\
\hline \multirow[t]{2}{*}{ Urban } & 51.556 & 64.653 & 36.082 & 48.659 \\
\hline & $(12.04)^{* *}$ & $(12.13)^{* *}$ & $(9.60)^{* *}$ & $(10.87)^{* *}$ \\
\hline \multirow[t]{2}{*}{ School equipment } & 9.168 & 10.696 & 6.979 & 8.702 \\
\hline & $(15.73)^{* *}$ & $(14.64)^{* *}$ & $(13.61)^{* *}$ & $(14.33)^{* *}$ \\
\hline \multirow[t]{2}{*}{ EC } & 32.628 & 39.475 & 33.793 & 55.108 \\
\hline & $(5.25)^{* *}$ & $(5.00)^{* *}$ & $(6.19)^{* *}$ & $(7.83)^{* *}$ \\
\hline \multirow[t]{2}{*}{ FS } & -38.958 & -45.521 & -26.88 & -22.359 \\
\hline & $(5.22)^{* *}$ & $(4.80) * *$ & $(4.11)^{* *}$ & $(2.62)^{* *}$ \\
\hline \multirow[t]{2}{*}{ GAU } & 44.552 & 33.873 & 43.722 & 69.211 \\
\hline & $(6.34)^{* *}$ & $(3.86)^{* *}$ & $(7.11)^{* *}$ & $(9.24)^{* * *}$ \\
\hline \multirow[t]{2}{*}{ KZN } & 56.944 & 67.01 & 62.652 & 89.567 \\
\hline & $(9.21)^{* *}$ & $(8.62)^{* *}$ & $(11.58)^{* *}$ & $(13.05)^{* *}$ \\
\hline \multirow[t]{2}{*}{ LIM } & 28.262 & 39.703 & 32.245 & 43.917 \\
\hline & $(4.50)^{* *}$ & $(4.90)^{* *}$ & $(5.86)^{* *}$ & $(6.17)^{* *}$ \\
\hline \multirow[t]{2}{*}{ MPU } & 8.224 & 17.208 & 15.762 & 24.345 \\
\hline & $(1.20)$ & $(1.98)^{*}$ & $(2.62)^{* *}$ & $(3.16)^{* *}$ \\
\hline \multirow[t]{2}{*}{$\mathrm{NC}$} & -15.473 & -4.458 & -7.071 & -10.221 \\
\hline & $(2.05)^{*}$ & $(0.47)$ & $(1.07)$ & $(1.21)$ \\
\hline $\mathrm{WC}$ & 93.318 & 80.023 & 75.014 & 114.838 \\
\hline
\end{tabular}




\begin{tabular}{|l|r|r|r|r|}
\hline & $(11.80)^{* *}$ & $(8.14)^{* *}$ & $(10.84)^{* *}$ & $(13.21)^{* *}$ \\
\hline Constant & 390.828 & 438.968 & 397.117 & 427.257 \\
\hline Observations & $(54.43)^{* *}$ & $(46.81)^{* *}$ & $(63.11)^{* *}$ & $(54.85)^{* *}$ \\
\hline Pseudo-R-squared & 3139 & 3139 & 3113 & 3113 \\
\hline
\end{tabular}

Absolute value of $t$ statistics in parentheses.

* significant at $5 \%$ level

** significant at $1 \%$ level 
Table 8: Regressions of school performance on reading and mathematics test

\begin{tabular}{|c|c|c|c|c|}
\hline & \multicolumn{2}{|c|}{ Reading } & \multicolumn{2}{|c|}{ Mathematics } \\
\hline & Regression 1 & Regression 2 & Regression 3 & Regression 4 \\
\hline \multirow[t]{2}{*}{$\%$ Under12 } & -59.116 & -66.639 & -124.319 & -135.436 \\
\hline & $(2.31)^{*}$ & $(2.63)^{* *}$ & $(4.21) * *$ & $(4.80) * *$ \\
\hline \multirow[t]{2}{*}{$\%$ Over12 } & -47.781 & -54.467 & -73.033 & -84.540 \\
\hline & $(1.83)$ & $(2.11)^{*}$ & $(2.72)^{* *}$ & $(3.37)^{* *}$ \\
\hline \multirow[t]{2}{*}{$\%$ Male } & -95.883 & -77.737 & -72.106 & -53.213 \\
\hline & $(2.47)^{*}$ & $(1.98)^{*}$ & $(1.98)^{*}$ & $(1.41)$ \\
\hline \multirow[t]{2}{*}{$\%$ Always spoke English at home } & 74.337 & 73.661 & 69.752 & 71.497 \\
\hline & $(3.38)^{* *}$ & $(3.34)^{* *}$ & $(3.47)^{* *}$ & $(3.42)^{* *}$ \\
\hline \multirow[t]{2}{*}{$\%$ NeverRepeated } & 85.060 & 92.276 & 82.293 & 91.063 \\
\hline & $(3.61)^{* *}$ & $(3.90) * *$ & $(3.25)^{* *}$ & $(3.65)^{* *}$ \\
\hline \multirow[t]{2}{*}{ SES } & 8.391 & 7.517 & 3.736 & 3.085 \\
\hline & $(2.79)^{* *}$ & $(2.42)^{*}$ & $(1.27)$ & $(1.00)$ \\
\hline \multirow[t]{2}{*}{ Urban } & 33.241 & 35.575 & 24.862 & 27.619 \\
\hline & $(2.98)^{* *}$ & $(3.20)^{* *}$ & $(2.28)^{*}$ & $(2.55)^{*}$ \\
\hline \multirow[t]{2}{*}{$\%$ Mother degree } & 142.092 & & 152.819 & \\
\hline & $(3.77)^{* *}$ & & $(4.14)^{* *}$ & \\
\hline \multirow[t]{2}{*}{$\%$ Mother at least matric } & & 59.395 & & 51.957 \\
\hline & & $(2.86)^{* *}$ & & $(2.44)^{*}$ \\
\hline \multirow[t]{2}{*}{$\%$ Sharetxtbkwithone } & 39.543 & 38.318 & & \\
\hline & $(2.23)^{*}$ & $(2.11)^{*}$ & & \\
\hline \multirow[t]{2}{*}{$\%$ Owntxtbook } & 42.628 & 40.354 & 30.441 & 29.218 \\
\hline & $(3.38)^{* *}$ & $(3.25)^{* *}$ & $(2.34)^{*}$ & $(2.24) *$ \\
\hline \multirow[t]{2}{*}{ School equipment } & 5.272 & 5.571 & 3.916 & 4.196 \\
\hline & $(4.83) * *$ & $(4.96) * *$ & $(3.59)^{* *}$ & $(3.60) * *$ \\
\hline \multirow[t]{2}{*}{ Constant } & 432.649 & 417.249 & 463.349 & 451.835 \\
\hline & $(13.49)^{* *}$ & $(12.42)^{* *}$ & $(14.49)^{* *}$ & $(13.88)^{* *}$ \\
\hline Observations & 167 & 167 & 167 & 167 \\
\hline R-squared & 0.79 & 0.78 & 0.71 & 0.69 \\
\hline
\end{tabular}

Absolute value of $t$ statistics in parentheses; Huber-White robust standard errors reported to deal with possible heteroskedasticity.

* significant at $5 \%$ level

** significant at $1 \%$ level 
Table 9: Hierarchical linear model for reading scores

\begin{tabular}{|c|c|c|c|c|c|c|}
\hline & & Coefficient & $\begin{array}{c}\text { Standard } \\
\text { error }\end{array}$ & t-value & $\begin{array}{c}\text { Degrees of } \\
\text { freedom }\end{array}$ & Significance \\
\hline \multicolumn{7}{|l|}{ Model for intercept } \\
\hline Intercept & $\gamma_{00}$ & 446.870 & 13.309 & 33.58 & 153 & 0.000 \\
\hline Mean SES & $\gamma_{01}$ & 21.893 & 4.087 & 5.36 & 153 & 0.000 \\
\hline \multicolumn{7}{|c|}{ Model for SES slope: } \\
\hline Intercept & $\gamma_{70}$ & 5.174 & 1.221 & 4.24 & 153 & 0.000 \\
\hline Mean SES & $\gamma_{71}$ & 2.191 & 0.855 & 2.56 & 153 & 0.012 \\
\hline \multicolumn{7}{|c|}{ Other fixed effects: } \\
\hline Over12 & $\beta_{1}$ & -18.924 & 3.361 & -5.63 & 2886 & 0.000 \\
\hline Male & $\beta_{2}$ & -11.171 & 2.772 & -4.03 & 2886 & 0.000 \\
\hline EnglishSometimes & $\beta_{3}$ & 14.456 & 3.200 & 4.52 & 2886 & 0.000 \\
\hline EnglishAlways & $\beta_{4}$ & 17.326 & 4.777 & 3.63 & 2886 & 0.001 \\
\hline Livedwithparents & $\beta_{5}$ & 7.998 & 3.193 & 2.51 & 2886 & 0.013 \\
\hline AbsentFeesUnpaid & $\beta_{6}$ & -19.532 & 6.989 & -2.80 & 2886 & 0.006 \\
\hline Boooks11plus & $\beta_{8}$ & 8.980 & 3.398 & 2.64 & 2886 & 0.009 \\
\hline Repeat Once & $\beta_{9}$ & -15.214 & 3.402 & -4.47 & 2886 & 0.000 \\
\hline Repeat Twice & $\beta_{10}$ & -24.692 & 5.073 & -4.87 & 2886 & 0.000 \\
\hline Repeat 3+ times & $\beta_{11}$ & -26.592 & 5.185 & -5.13 & 2886 & 0.000 \\
\hline Homew2 & $\beta_{12}$ & 9.785 & 4.819 & 2.03 & 2886 & 0.042 \\
\hline Homew3 & $\beta_{13}$ & 8.004 & 4.333 & 1.85 & 2886 & 0.064 \\
\hline Notextbook & $\beta_{14}$ & -10.785 & 3.789 & -2.85 & 2886 & 0.005 \\
\hline MotherMatric & $\beta_{15}$ & 7.538 & 3.930 & 1.92 & 2886 & 0.055 \\
\hline $\mathrm{FS}$ & $\beta_{16}$ & -5.678 & 13.892 & -0.41 & 2886 & 0.682 \\
\hline GAU & $\beta_{17}$ & 68.793 & 19.994 & 3.44 & 2886 & 0.001 \\
\hline KZN & $\beta_{18}$ & 48.384 & 13.977 & 3.46 & 2886 & 0.001 \\
\hline LIM & $\beta_{19}$ & 19.966 & 14.203 & 1.41 & 2886 & 0.160 \\
\hline MPU & $\beta_{20}$ & 12.055 & 14.647 & 0.82 & 2886 & 0.411 \\
\hline $\mathrm{NC}$ & $\beta_{21}$ & 25.874 & 15.873 & 1.63 & 2886 & 0.103 \\
\hline EC & $\beta_{22}$ & 19.594 & 14.806 & 1.32 & 2886 & 0.186 \\
\hline $\mathrm{WC}$ & $\beta_{23}$ & 86.619 & 18.565 & 4.67 & 2886 & 0.000 \\
\hline Random effects & & $\begin{array}{l}\text { Standard } \\
\text { deviation }\end{array}$ & Variance & Chi-square & $\begin{array}{c}\text { Degrees of } \\
\text { freedom }\end{array}$ & P-value \\
\hline Intercept & $\mathrm{U}_{0}$ & 52.283 & 2733.513 & 1163.697 & 153 & 0.000 \\
\hline Mean-SES & $\mathrm{U}_{7}$ & 9.126 & 83.276 & 297.412 & 153 & 0.000 \\
\hline Level 1 & $\mathrm{R}$ & 61.181 & 3743.171 & & & \\
\hline
\end{tabular}

Note: Robust standard errors reported. 
Table 10: Hierarchical linear model for mathematic score

\begin{tabular}{|c|c|c|c|c|c|c|}
\hline & & Coefficient & $\begin{array}{c}\text { Standard } \\
\text { error }\end{array}$ & t-value & $\begin{array}{l}\text { Degrees of } \\
\text { freedom }\end{array}$ & Significance \\
\hline \multicolumn{7}{|c|}{ Model for intercept: } \\
\hline Intercept & $\gamma_{00}$ & 420.752 & 12.817 & 32.83 & 153 & 0.000 \\
\hline Mean SES & $\gamma_{01}$ & 14.979 & 3.679 & 4.07 & 153 & 0.000 \\
\hline \multicolumn{7}{|c|}{ Model for SES slope: } \\
\hline Intercept & $\gamma_{70}$ & 4.095 & 1.031 & 3.97 & 153 & 0.000 \\
\hline Mean SES & $\gamma_{71}$ & 2.380 & 0.715 & 3.33 & 153 & 0.001 \\
\hline \multicolumn{7}{|c|}{ Other fixed effects: } \\
\hline Over12 & $\beta_{1}$ & -11.989 & 2.565 & -4.67 & 2863 & 0.000 \\
\hline Male & $\beta_{2}$ & 1.916 & 2.571 & 0.75 & 2863 & 0.456 \\
\hline EnglishSometimes & $\beta_{3}$ & 12.316 & 3.793 & 3.25 & 2863 & 0.002 \\
\hline EnglishAlways & $\beta_{4}$ & 17.671 & 4.961 & 3.56 & 2863 & 0.001 \\
\hline Livedwithparents & $\beta_{5}$ & 10.644 & 3.162 & 3.37 & 2863 & 0.001 \\
\hline AbsentFeesUnpaid & $\beta_{6}$ & -12.518 & 5.994 & -2.09 & 2863 & 0.037 \\
\hline Boooks11plus & $\beta_{8}$ & 7.904 & 3.332 & 2.37 & 2863 & 0.018 \\
\hline Repeat Once & $\beta_{9}$ & -11.279 & 3.025 & -3.73 & 2863 & 0.000 \\
\hline Repeat Twice & $\beta_{10}$ & -12.626 & 4.687 & -2.69 & 2863 & 0.008 \\
\hline Repeat 3+ times & $\beta_{11}$ & -20.574 & 4.862 & -4.23 & 2863 & 0.000 \\
\hline Absentfromschool & $\beta_{12}$ & -1.422 & 0.581 & -2.45 & 2863 & 0.015 \\
\hline MotherMatric & $\beta_{13}$ & 6.252 & 3.266 & 1.91 & 2863 & 0.055 \\
\hline FS & $\beta_{14}$ & 11.133 & 13.241 & 0.84 & 2863 & 0.401 \\
\hline GAU & $\beta_{15}$ & 69.453 & 17.362 & 4.00 & 2863 & 0.000 \\
\hline KZN & $\beta_{16}$ & 67.251 & 16.423 & 4.10 & 2863 & 0.000 \\
\hline LIM & $\beta_{17}$ & 34.922 & 14.851 & 2.35 & 2863 & 0.019 \\
\hline MPU & $\beta_{18}$ & 21.661 & 13.772 & 1.57 & 2863 & 0.116 \\
\hline $\mathrm{NC}$ & $\beta_{19}$ & 38.639 & 13.887 & 2.78 & 2863 & 0.006 \\
\hline $\mathrm{EC}$ & $\beta_{20}$ & 36.618 & 13.782 & 2.66 & 2863 & 0.008 \\
\hline $\mathrm{WC}$ & $\beta_{21}$ & 90.146 & 19.868 & 4.54 & 2863 & 0.000 \\
\hline Random effects & & $\begin{array}{l}\text { Standard } \\
\text { deviation }\end{array}$ & Variance & $\begin{array}{c}\text { Chi- } \\
\text { square }\end{array}$ & $\begin{array}{l}\text { Degrees of } \\
\text { freedom }\end{array}$ & P-value \\
\hline Intercept & $\mathrm{U}_{0}$ & 48.499 & 2352.126 & 828.542 & 153 & 0.0000 \\
\hline Mean-SES & $\mathrm{U}_{7}$ & 6.765 & 45.769 & 208.530 & 153 & 0.0020 \\
\hline Level 1 & $\mathrm{R}$ & 62.257 & 3875.956 & & & \\
\hline
\end{tabular}

Note: Robust standard errors reported. 
Figure 1: Differential in reading and mathematics performance between high and low socio-economic status group by country: SACMEQ II

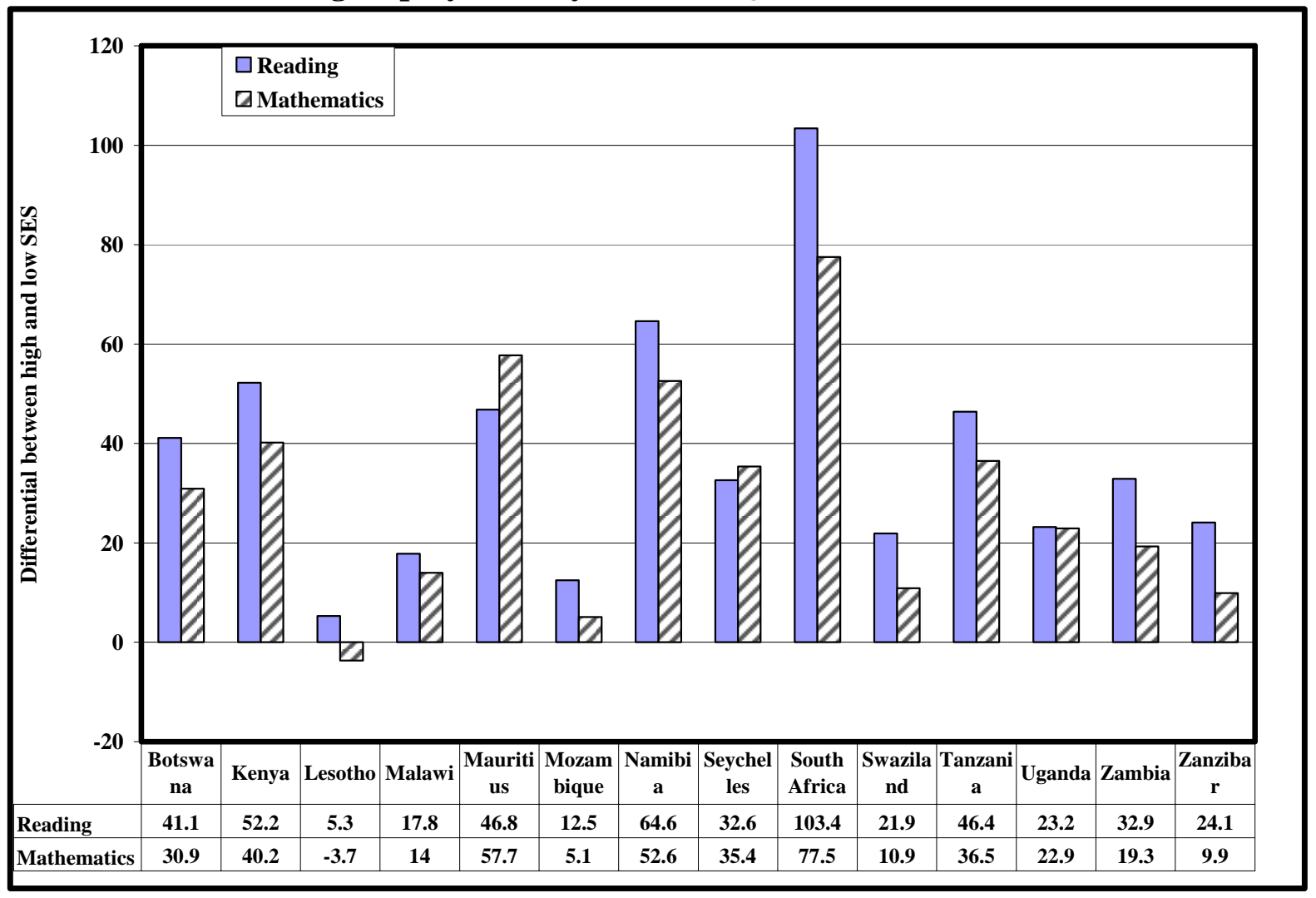

Source: Derived from indicators on SACMEQ website. Available online at: http://www.sacmeq.org/indicate.htm 
Figure 2: Differential in reading and mathematics performance between large cities and isolated rural areas by country: SACMEQ II

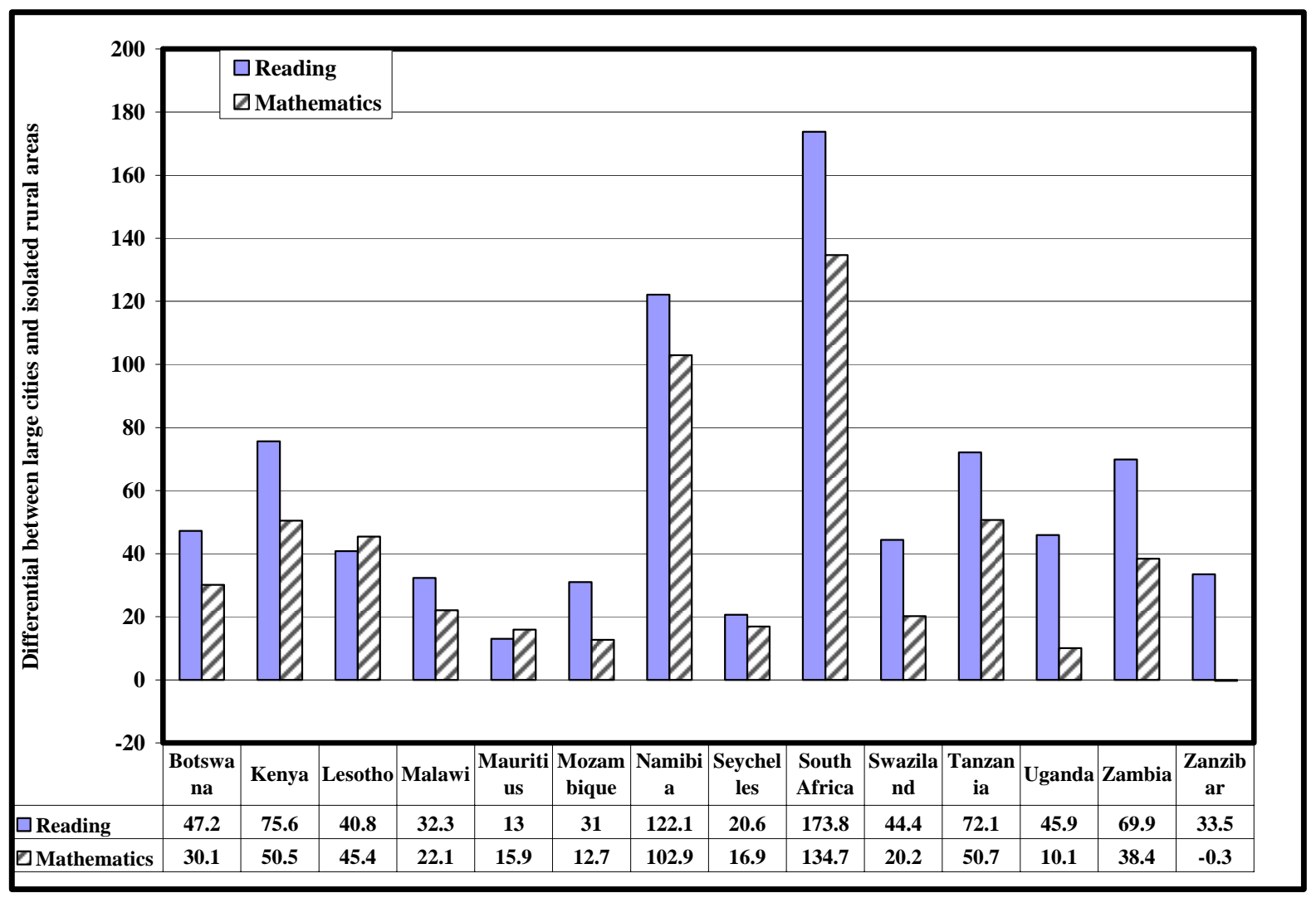

Source: Derived from indicators on SACMEQ website. Available online at: http://www.sacmeq.org/indicate.htm 
Figure 3a \& 3b: Lowess regression: Individual reading score vs. SES and Average Reading Score vs. mean school SES

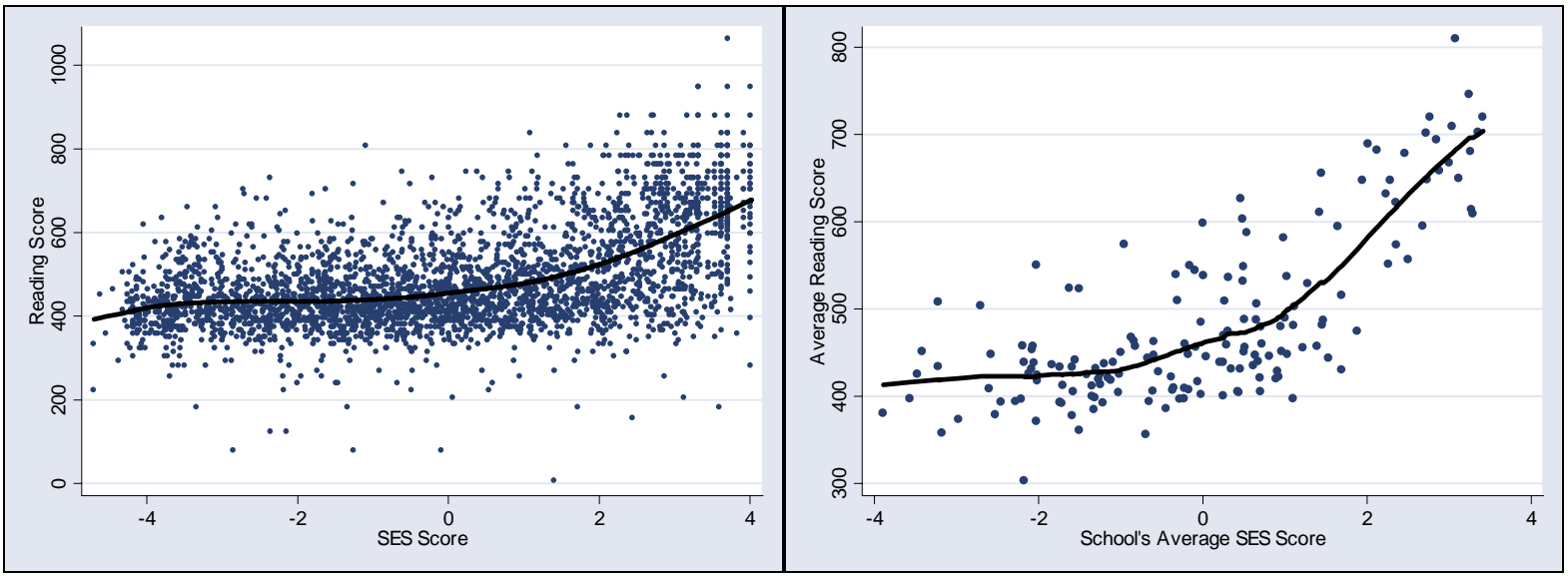

Figure 4a \& 4b: Lowess regression: Individual mathematics score vs. SES and Average Mathematics Score vs. mean school SES

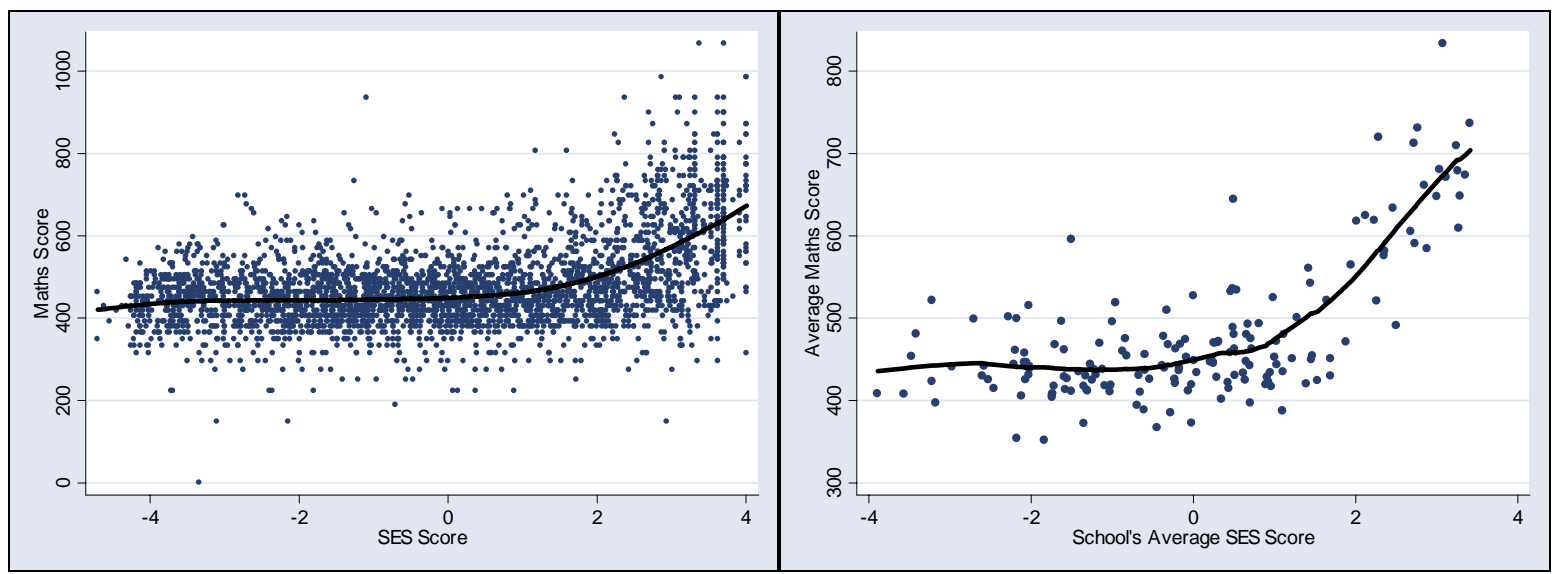


Figure 5: Effect of individual socio-economic status on reading test scores as derived from HLM model for poor, average and rich schools (for reference person)

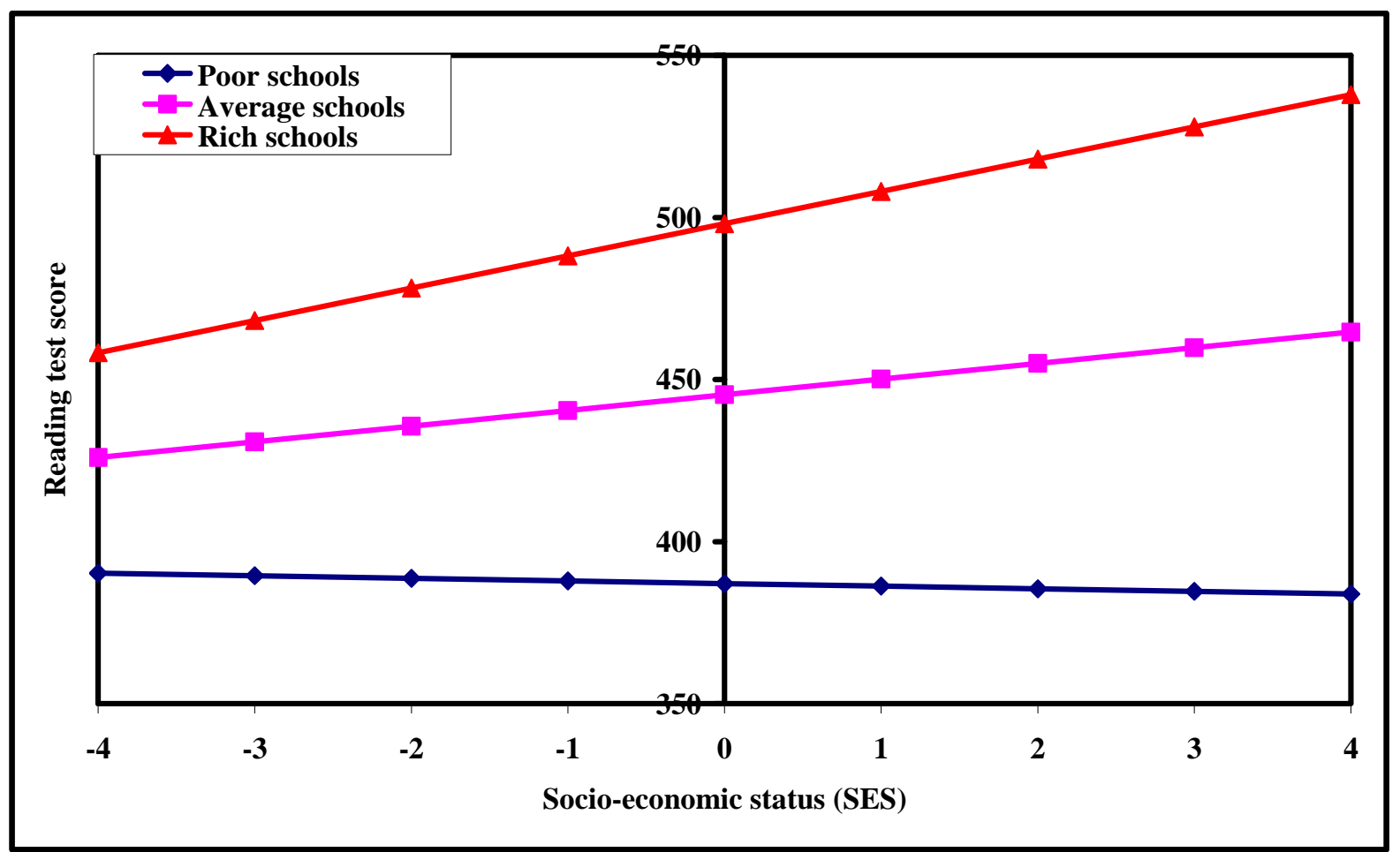

Note: From the model in Equation 4, the regression lines for the reference person reduced to:

$$
\text { Score }=\gamma 00+\gamma 01 * \text { MeanSES }+\gamma 70 * S E S+\gamma 71 * S E S * M e a n S E S
$$

This was applied above to each of the three SES school types. 


\section{Bisher erschienene Diskussionspapiere}

Nr. 69: Van der Berg, Servaas: How effective are poor schools? Poverty and educational outcomes in South Africa, Januar 2008

Nr. 68: Kühl, Michael: Cointegration in the Foreign Exchange Market and Market Efficiency since the Introduction of the Euro: Evidence based on bivariate Cointegration Analyses, Oktober 2007

Nr. 67: Hess, Sebastian, Cramon-Taubadel, Stephan von: Assessing General and Partial Equilibrium Simulations of Doha Round Outcomes using Meta-Analysis, August 2007

Nr. 66: Eckel, Carsten: International Trade and Retailing: Diversity versus Accessibility and the Creation of “Retail Deserts”, August 2007

Nr. 65: Stoschek, Barbara: The Political Economy of Enviromental Regulations and Industry Compensation, Juni 2007

Nr. 64: Martinez-Zarzoso, Inmaculada; Nowak-Lehmann D., Felicitas; Vollmer, Sebastian: The Log of Gravity Revisited, Juni 2007

Nr. 63: Gundel, Sebastian: Declining Export Prices due to Increased Competition from NIC Evidence from Germany and the CEEC, April 2007

Nr. 62: Wilckens, Sebastian: Should WTO Dispute Settlement Be Subsidized?, April 2007

Nr. 61: Schöller, Deborah: Service Offshoring: A Challenge for Employment? Evidence from Germany, April 2007

Nr. 60: Janeba, Eckhard: Exports, Unemployment and the Welfare State, März 2007

Nr. 59: Lambsdoff, Johann Graf; Nell, Mathias: Fighting Corruption with Asymmetric Penalties and Leniency, Februar 2007

Nr. 58: Köller, Mareike: Unterschiedliche Direktinvestitionen in Irland - Eine theoriegestützte Analyse, August 2006

Nr. 57: Entorf, Horst; Lauk, Martina: Peer Effects, Social Multipliers and Migrants at School: An International Comparison, März 2007 (revidierte Fassung von Juli 2006)

Nr. 56: Görlich, Dennis; Trebesch, Christoph: Mass Migration and Seasonality Evidence on Moldova's Labour Exodus, Mai 2006

Nr. 55: Brandmeier, Michael: Reasons for Real Appreciation in Central Europe, Mai 2006

Nr. 54: Martínez-Zarzoso, Inmaculada; Nowak-Lehmann D., Felicitas: Is Distance a Good Proxy for Transport Costs? The Case of Competing Transport Modes, Mai 2006

Nr. 53: Ahrens, Joachim; Ohr, Renate; Zeddies, Götz: Enhanced Cooperation in an Enlarged EU, April 2006

Nr. 52: Stöwhase, Sven: Discrete Investment and Tax Competition when Firms shift Profits, April 2006

Nr. 51: Pelzer, Gesa: Darstellung der Beschäftigungseffekte von Exporten anhand einer InputOutput-Analyse, April 2006

Nr. 50: Elschner, Christina; Schwager, Robert: A Simulation Method to Measure the Tax Burden on Highly Skilled Manpower, März 2006

Nr. 49: Gaertner, Wulf; Xu, Yongsheng: A New Measure of the Standard of Living Based on Functionings, Oktober 2005

Nr. 48: Rincke, Johannes; Schwager, Robert: Skills, Social Mobility, and the Support for the Welfare State, September 2005

Nr. 47: Bose, Niloy; Neumann, Rebecca: Explaining the Trend and the Diversity in the Evolution of the Stock Market, Juli 2005 
Nr. 46: Kleinert, Jörn; Toubal, Farid: Gravity for FDI, Juni 2005

Nr. 45: Eckel, Carsten: International Trade, Flexible Manufacturing and Outsourcing, Mai 2005

Nr. 44: Hafner, Kurt A.: International Patent Pattern and Technology Diffusion, Mai 2005

Nr. 43: Nowak-Lehmann D., Felicitas; Herzer, Dierk; Martínez-Zarzoso, Inmaculada; Vollmer, Sebastian: Turkey and the Ankara Treaty of 1963: What can Trade Integration Do for Turkish Exports, Mai 2005

Nr. 42: Südekum, Jens: Does the Home Market Effect Arise in a Three-Country Model?, April 2005

Nr. 41: Carlberg, Michael: International Monetary Policy Coordination, April 2005

Nr. 40: Herzog, Bodo: Why do bigger countries have more problems with the Stability and Growth Pact?, April 2005

Nr. 39: Marouani, Mohamed A.: The Impact of the Mulitfiber Agreement Phaseout on Unemployment in Tunisia: a Prospective Dynamic Analysis, Januar 2005

Nr. 38: Bauer, Philipp; Riphahn, Regina T.: Heterogeneity in the Intergenerational Transmission of Educational Attainment: Evidence from Switzerland on Natives and Second Generation Immigrants, Januar 2005

Nr. 37: Büttner, Thiess: The Incentive Effect of Fiscal Equalization Transfers on Tax Policy, Januar 2005

Nr. 36: Feuerstein, Switgard; Grimm, Oliver: On the Credibility of Currency Boards, Oktober 2004

Nr. 35: Michaelis, Jochen; Minich, Heike: Inflationsdifferenzen im Euroraum - eine Bestandsaufnahme, Oktober 2004

Nr. 34: Neary, J. Peter: Cross-Border Mergers as Instruments of Comparative Advantage, Juli 2004

Nr. 33: Bjorvatn, Kjetil; Cappelen, Alexander W.: Globalisation, inequality and redistribution, Juli 2004

Nr. 32: Stremmel, Dennis: Geistige Eigentumsrechte im Welthandel: Stellt das TRIPs-Abkommen ein Protektionsinstrument der Industrieländer dar?, Juli 2004

Nr. 31: Hafner, Kurt: Industrial Agglomeration and Economic Development, Juni 2004

Nr. 30: Martinez-Zarzoso, Inmaculada; Nowak-Lehmann D., Felicitas: MERCOSUR-European Union Trade: How Important is EU Trade Liberalisation for MERCOSUR's Exports?, Juni 2004

Nr. 29: Birk, Angela; Michaelis, Jochen: Employment- and Growth Effects of Tax Reforms, Juni 2004

Nr. 28: Broll, Udo; Hansen, Sabine: Labour Demand and Exchange Rate Volatility, Juni 2004

Nr. 27: Bofinger, Peter; Mayer, Eric: Monetary and Fiscal Policy Interaction in the Euro Area with different assumptions on the Phillips curve, Juni 2004

Nr. 26: Torlak, Elvisa: Foreign Direct Investment, Technology Transfer and Productivity Growth in Transition Countries, Juni 2004

Nr. 25: Lorz, Oliver; Willmann, Gerald: On the Endogenous Allocation of Decision Powers in Federal Structures, Juni 2004

Nr. 24: Felbermayr, Gabriel J.: Specialization on a Technologically Stagnant Sector Need Not Be Bad for Growth, Juni 2004

Nr. 23: Carlberg, Michael: Monetary and Fiscal Policy Interactions in the Euro Area, Juni 2004

Nr. 22: Stähler, Frank: Market Entry and Foreign Direct Investment, Januar 2004

Nr. 21: Bester, Helmut; Konrad, Kai A.: Easy Targets and the Timing of Conflict, Dezember 2003

Nr. 20: Eckel, Carsten: Does globalization lead to specialization, November 2003 
Nr. 19: Ohr, Renate; Schmidt, André: Der Stabilitäts- und Wachstumspakt im Zielkonflikt zwischen fiskalischer Flexibilität und Glaubwürdigkeit: Ein Reform-ansatz unter Berücksichtigung konstitutionen- und institutionenökonomischer Aspekte, August 2003

Nr. 18: Ruehmann, Peter: Der deutsche Arbeitsmarkt: Fehlentwicklungen, Ursachen und Reformansätze, August 2003

Nr. 17: Suedekum, Jens: Subsidizing Education in the Economic Periphery: Another Pitfall of Regional Policies?, Januar 2003

Nr. 16: Graf Lambsdorff, Johann; Schinke, Michael: Non-Benevolent Central Banks, Dezember 2002

Nr. 15: Ziltener, Patrick: Wirtschaftliche Effekte des EU-Binnenmarktprogramms, November 2002

Nr. 14: Haufler, Andreas; Wooton, Ian: Regional Tax Coordination and Foreign Direct Investment, November 2001

Nr. 13: Schmidt, André: Non-Competition Factors in the European Competition Policy: The Necessity of Institutional Reforms, August 2001

Nr. 12: Lewis, Mervyn K.: Risk Management in Public Private Partnerships, Juni 2001

Nr. 11: Haaland, Jan I.; Wooton, Ian: Multinational Firms: Easy Come, Easy Go?, Mai 2001

Nr. 10: Wilkens, Ingrid: Flexibilisierung der Arbeit in den Niederlanden: Die Entwicklung atypischer Beschäftigung unter Berücksichtigung der Frauenerwerbstätigkeit, Januar 2001

Nr. 9: Graf Lambsdorff, Johann: How Corruption in Government Affects Public Welfare - A Review of Theories, Januar 2001

Nr. 8: $\quad$ Angermüller, Niels-Olaf: Währungskrisenmodelle aus neuerer Sicht, Oktober 2000

Nr. 7: $\quad$ Nowak-Lehmann, Felicitas: Was there Endogenous Growth in Chile (1960-1998)? A Test of the AK model, Oktober 2000

Nr. 6: $\quad$ Lunn, John; Steen, Todd P.: The Heterogeneity of Self-Employment: The Example of Asians in the United States, Juli 2000

Nr. 5: Güßefeldt, Jörg; Streit, Clemens: Disparitäten regionalwirtschaftlicher Entwicklung in der EU, Mai 2000

Nr. 4: Haufler, Andreas: Corporate Taxation, Profit Shifting, and the Efficiency of Public Input Provision, 1999

Nr. 3: Rühmann, Peter: European Monetary Union and National Labour Markets, September 1999

Nr. 2: Jarchow, Hans-Joachim: Eine offene Volkswirtschaft unter Berücksichtigung des Aktienmarktes, 1999

Nr. 1: Padoa-Schioppa, Tommaso: Reflections on the Globalization and the Europeanization of the Economy, Juni 1999

Alle bisher erschienenen Diskussionspapiere zum Download finden Sie im Internet unter: http://www.uni-goettingen.de/de/60920.html. 